Provided for non-commercial research and education use. Not for reproduction, distribution or commercial use.

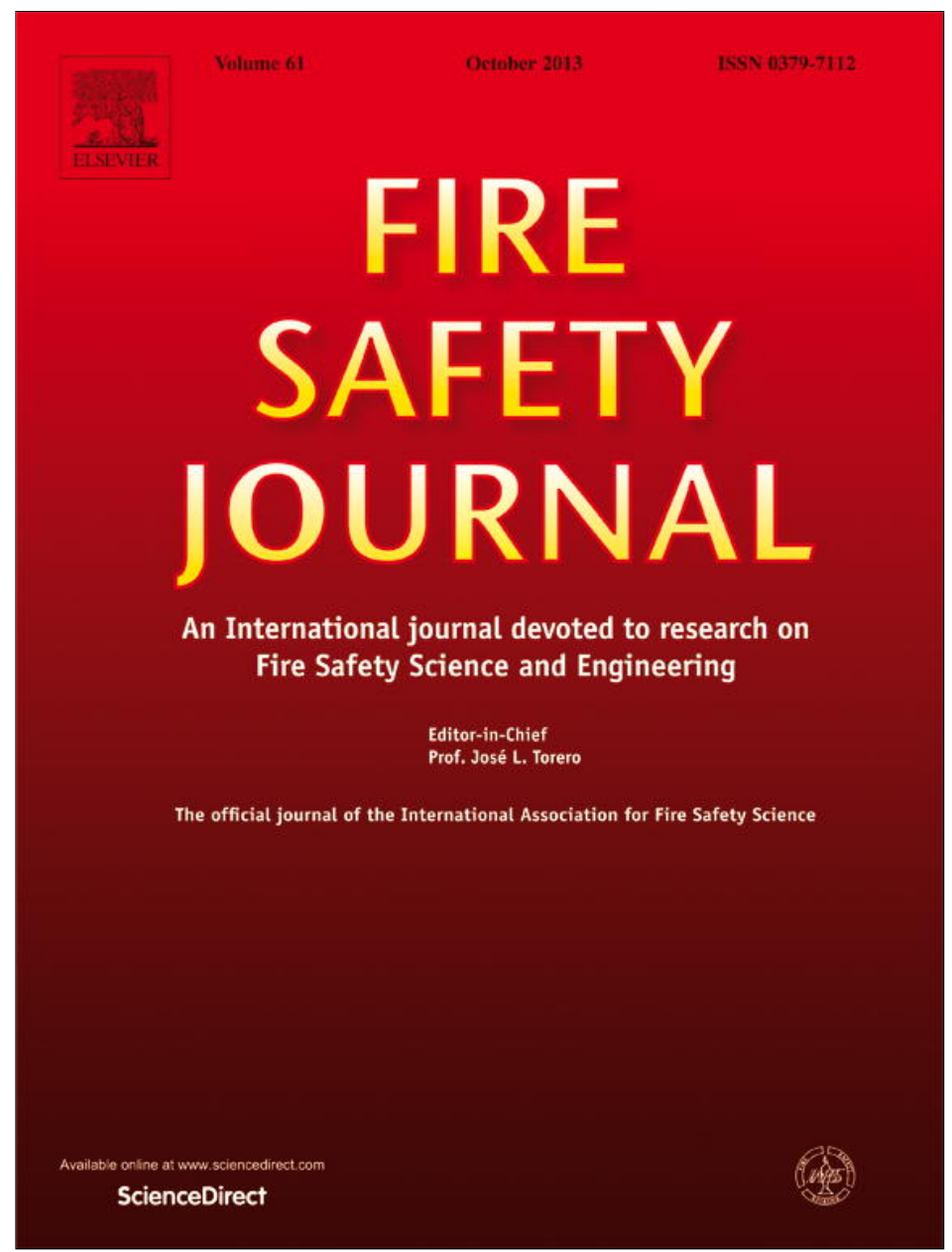

This article appeared in a journal published by Elsevier. The attached copy is furnished to the author for internal non-commercial research and education use, including for instruction at the authors institution and sharing with colleagues.

Other uses, including reproduction and distribution, or selling or licensing copies, or posting to personal, institutional or third party websites are prohibited.

In most cases authors are permitted to post their version of the article (e.g. in Word or Tex form) to their personal website or institutional repository. Authors requiring further information regarding Elsevier's archiving and manuscript policies are encouraged to visit:

http://www.elsevier.com/authorsrights 


\title{
Heat release rate measurements of burning mining vehicles in an underground mine
}

\author{
Rickard Hansen ${ }^{\mathrm{a}, *}$, Haukur Ingason ${ }^{\mathrm{a}, \mathrm{b}}$ \\ a Mälardalen University, Box 833, S-721 23 Västerås, Sweden \\ b SP Technical Research Institute of Sweden, Box 857, 50115 Borås, Sweden
}

\section{A R T I C L E I N F O}

\section{Article history:}

Received 1 October 2012

Received in revised form

1 August 2013

Accepted 4 August 2013

Available online 25 August 2013

\section{Keywords:}

Heat release rate

Mining vehicle

Full-scale fire experiment

Underground mine

\begin{abstract}
A B S T R A C T
Heat release rates from two full-scale fire experiments with mining vehicles in an underground mine are presented. The mining vehicles involved were a wheel loader and a drilling rig typical for mining operations. The calculated peak heat release rate of the loader was $15.9 \mathrm{MW}$ and occurred after approximately $11 \mathrm{~min}$ from ignition. The calculated peak heat release rate of the drilling rig was 29.4 MW and occurred after approximately $21 \mathrm{~min}$ from ignition. The heat release rate was calculated from measured data of gas concentrations of oxygen, carbon monoxide and carbon dioxide, measured gas velocity and measured gas temperatures. The fuel load of the wheel loader consisted mainly of the tyres, the hydraulic oil and the diesel fuel. The fuel load of the drilling rig consisted mainly of the hydraulic oil and the hydraulic hoses. The calculated heat release rate curves were controlled by comparing the summed up energy contents of the participating components with the integrated heat release rate curves.
\end{abstract}

(c) 2013 Elsevier Ltd. All rights reserved.

\section{Introduction}

The aim of the full-scale fire experiments presented here was to determine the heat release rate (HRR) for vehicles common in the mining industry. Studies show that vehicles or mobile equipment are the dominating fire object in underground mines [1,2]. The studies show that the better knowledge about fire spread is needed for service vehicles, drilling rigs and loaders. The information from full-scale fire experiments in an underground mine would be most valuable for companies manufacturing underground vehicles as well as mining companies and first responders. The information is also important for the design of evacuation procedures and equipment such as rescue chamber. For example the results can be used in the design process of the fire safety engineering of mines. Information about the fire spread and the HRR of vehicles and mobile equipment is the base in the preventive fire safety work.

There is only one full-scale fire experiment using large vehicle in an underground mine that has been performed and documented earlier [3]. The experiment was carried out in a loader CAT 960, where the fuel load consisted of rubber $(2200 \mathrm{~kg})$ and oil $(600 \mathrm{l})$. The aim of the experiment was to investigate the environment that a mobile rescue chamber was exposed to during a fire. During

\footnotetext{
* Corresponding author. Tel.: +46 705778759.

E-mail addresses: rickard.hansen@mdh.se (R. Hansen) haukur.ingason@sp.se (H. Ingason)
}

the experiment the carbon monoxide (CO)-level and temperature inside and outside the rescue chamber were continually measured; the smoke density at the rescue chamber and the airflow in the drift (the term "drift" in this text corresponds to a horizontal passage in an underground mine) was measured; and the experiment was videotaped. Unfortunately no HRR measurements were conducted during the experiment. This information is vital for engineers working with fire safety in underground mines and tunnel construction sites.

Several full-scale fire tests on vehicles or parts of vehicles have been conducted in traffic tunnels, such as the tests involving a heavy goods vehicle (HGV) mock-ups trailer cargo in Runehamar, Norway [4]. The commodity on the trailer mock-up consisted of furniture, polyurethane mattresses, truck tyres etc. The estimated maximum heat release rates were in the interval 66-202 MW [4]. The method of determine the heat release rate using oxygen consumption calorimetry has been applied here [5]. The method uses the possibility to analyse the combustion gases on the downstream side of the air flow. The accuracy of the method has been estimated and will be discussed separately in this paper. In the following a description of the tests and test-setup is given.

\section{The mining vehicles}

Two full-scale fire tests were carried out, one with a wheel loader and one with a drilling rig. Each of these vehicles has been 


\begin{tabular}{|c|c|c|c|}
\hline \multicolumn{2}{|c|}{ Notation } & $t$ & $=$ time $(\mathrm{s})$ \\
\hline A & $=$ cross-sectional area $\left(\mathrm{m}^{2}\right)$ & 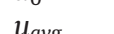 & $=$ average longitudinal velocity in a mine $\mathrm{drift}(\mathrm{m} / \mathrm{s})$ \\
\hline$c_{s t}$ & $=$ specific heat capacity of steel $(\mathrm{J} / \mathrm{kg} \mathrm{K})$ & $u_{\text {probe }}$ & $=$ ventilation velocity of bi directional probe $(\mathrm{m} / \mathrm{s})$ \\
\hline$h_{P T}$ & $=$ convective heat transfer coefficient of the plate & $X_{\mathrm{H}_{2} \mathrm{O}, 0}$ & $=$ mole fraction of water in the ambient air \\
\hline & thermometer $\left(\mathrm{W} / \mathrm{m}^{2} \mathrm{~K}\right)$ & $X_{\mathrm{O}_{2}, \text { avg }}$ & $=$ average concentration of oxygen \\
\hline$K_{\text {cond }}$ & $=$ conduction correction factor $\left(\mathrm{W} / \mathrm{m}^{2} \mathrm{~K}\right)$ & $X_{\mathrm{CO}, a v g}$ & $=$ average concentration of carbon monoxide \\
\hline $\begin{array}{l}M_{a} \text { cona } \\
M_{a}\end{array}$ & $=$ molecular weight of air & $X_{\mathrm{CO}_{2} \text {,avg }}$ & $=$ average concentration of carbon dioxide \\
\hline$M_{\mathrm{O}_{2}}$ & $=$ molecular weight of oxygen & $X_{\mathrm{O}_{2}, 0}$ & $=$ mole fraction of oxygen in the ambient air \\
\hline$N_{T}$ & $=$ number of measuring points with thermocouples & $X_{\mathrm{CO}, 0}$ & $=$ mole fraction of carbon monoxide in the ambient air \\
\hline$\Delta p$ & $=$ pressure difference $(\mathrm{Pa})$ & $X_{\mathrm{CO}_{2}, 0}$ & $=$ mole fraction of carbon dioxide in the ambient air \\
\hline$\dot{Q}$ & $=$ heat release rate $(\mathrm{HRR})(\mathrm{kW})$ & $X_{\mathrm{O}_{2}, h}$ & $=$ oxygen concentration at height $h$ \\
\hline$q^{\prime \prime}{ }_{i n c}$ & $=$ incident heat flux $\left(\mathrm{kW} / \mathrm{m}^{2}\right)$ & $X_{\mathrm{CO}_{2}, h}$ & $=$ carbon dioxide concentration at height $h$ \\
\hline$T$ & $=$ gas temperature $(\mathrm{K})$ & $X_{\mathrm{CO}, h}$ & $=$ carbon monoxide concentration at height $h$ \\
\hline$T_{\text {avg }}$ & $=$ average temperature in a mine $\operatorname{drift}(\mathrm{K})$ & $\delta$ & $=$ thickness of steel plate (plate thermometer) $(\mathrm{m})$ \\
\hline$T_{h}$ & $=$ temperature at height $h(\mathrm{~K})$ & $\varepsilon_{P T}$ & $=$ surface emissivity of the plate thermometer \\
\hline$T_{i}$ & $=$ temperature at thermocouple $i(\mathrm{~K})$ & $\rho_{\text {st }}$ & $=$ density of steel $\left(\mathrm{kg} / \mathrm{m}^{3}\right)$ \\
\hline$T_{0}$ & $=$ ambient temperature $(\mathrm{K})$ & $\rho_{0}$ & $=$ ambient air density $\left(\mathrm{kg} / \mathrm{m}^{3}\right)$ \\
\hline$T_{P T}$ & $=$ temperature of the plate thermometer $(\mathrm{K})$ & $\sigma$ & $=$ Stefan-Boltzmann constant, $5.67 \times 10^{-11} \mathrm{~kW} / \mathrm{m}^{2} \mathrm{~K}^{4}$ \\
\hline
\end{tabular}

in service for several years. In the following a detailed description of each mining vehicle used is given.

\subsection{Wheel loader}

A wheel loader of type Toro 501 DL was used in the first full-scale fire test. The wheel loader is a diesel driven vehicle commonly used in underground mines. The wheel loader is used for hauling iron ore between the production areas to a vertical shaft (i.e. an ore pass), where the iron ore is unloaded. In Table 1 below some basic information regarding geometry, weight etc of the Toro 501 wheel loader is given (Fig. 1).

Table 1

Basic technical information regarding the Toro 50 DL wheel loader obtained from the manufacturer.

\begin{tabular}{ll}
\hline Length & $10.3 \mathrm{~m}$ \\
Width & $2.81 \mathrm{~m}$ \\
Height & $2.85 \mathrm{~m}$ \\
Weight & $36,000 \mathrm{~kg}$ \\
Tyre dimensions & $26.5 \times 25 \mathrm{~L} 5 \mathrm{~S}$ \\
\hline
\end{tabular}

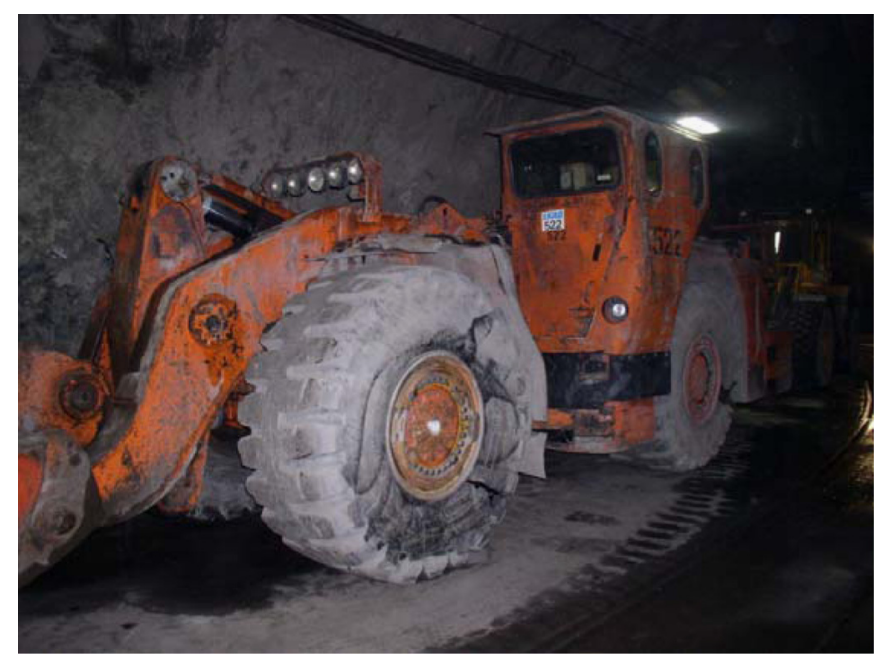

Fig. 1. The Toro 501 DL wheel loader used in the full-scale fire experiments in Sweden.
The fuel load of the actual wheel loader consists primarily of the four tyres. The tyre dimension $26.5 \times 25$ L5S implies a tyre with a section width of $26.5 \mathrm{in}$. $(0.66 \mathrm{~m})$, a rim diameter of $25 \mathrm{in}$. $(0.625 \mathrm{~m})$ and with smooth extra deep tread. In Table 2, an inventory of the combustible components is found. If all the combustible components found in Table 2 would have been consumed in the fire experiment, the total energy released during the experiment would have been $76.2 \mathrm{GJ}$. These numbers are based on onsite evaluation and inspection before the test. The tyres of the wheel loader were filled with water - instead of air - due to the risk of tyre explosion during normal operation. Each tyre contained 5771 of water $(75 \%$ of the interior volume of the tyre). Before the fire experiment, the scoop was removed. No other modifications were made on the wheel loader.

\subsection{The drilling rig}

A drilling rig was used in the second full-scale fire test. The drilling rig was an Atlas Copco Rocket Boomer 322, which is an electrically driven drilling rig commonly used in underground mines. The drilling rig is nonetheless equipped with a diesel powered engine which is used when moving the drilling rig from one site to another. In Table 3 some basic information regarding measurements, weight etc is given (Fig. 2).

The fuel load of the drilling rig consists primarily of the four tyres, the hydraulic oil and the hydraulic hoses. The tyre dimension $13.00 \times 20$ PR 18 implies a tyre with a section width of 13 in. $(0.325 \mathrm{~m})$ and a rim diameter of $20 \mathrm{in}$. $(0.5 \mathrm{~m})$. In Table 4 an inventory of the combustible components is found. The effective heat of combustion of the hydraulic hose was also applied for the water hose. No modifications on the drilling rig were made before the fire experiment. If all the combustible components found in Table 4 would have been consumed in the fire experiment, the total energy released during the experiment would have been $45.8 \mathrm{GJ}$.

\section{The experimental set-up}

The site of the full-scale fire experiments was the underground facilities of Björka Mineral AB on the outskirts of Sala, Sweden. The fire experiments were conducted at level 55 ( $55 \mathrm{~m}$ from the top of the mine) which is a non-active part of the mine that is connected 
Table 2

Inventory of combustible components found on the Toro 501 DL wheel loader.

\begin{tabular}{|c|c|c|c|c|c|}
\hline $\begin{array}{l}\text { Combustible } \\
\text { component }\end{array}$ & $\begin{array}{l}\text { Estimated amount } \\
\text { prior to test }\end{array}$ & $\begin{array}{l}\text { Effective heat of } \\
\text { combustion }[\mathrm{MJ} / \mathrm{kg}]\end{array}$ & $\begin{array}{l}\text { Estimated energy } \\
\text { content }[\mathrm{MJ}]\end{array}$ & $\begin{array}{l}\text { Mean heat release rate per } \\
\text { unit area }\left[\mathrm{kW} / \mathrm{m}^{2}\right]^{\mathrm{a}}\end{array}$ & Other \\
\hline Tyres & $1560 \mathrm{~kg}$ & $27[6]$ & 42,120 & & $\begin{array}{l}\text { Dimensions: overall width } 0.7 \mathrm{~m} \text {; overall } \\
\text { diameter } 1.8 \mathrm{~m}\end{array}$ \\
\hline $\begin{array}{l}\text { Hydraulic oil in } \\
\text { tank }\end{array}$ & 5001 & $42.85[7]$ & 16,283 & & Type: Shell Tellus VG46 \\
\hline $\begin{array}{l}\text { Hydraulic oil in } \\
\text { hoses }\end{array}$ & 701 & $42.85[7]$ & 2,280 & & Type: Shell Tellus VG46 \\
\hline $\begin{array}{l}\text { Hydraulic } \\
\text { hoses }\end{array}$ & $170 \mathrm{~kg}$ & $28.85^{\mathrm{b}}$ & 4,905 & $152^{\mathrm{c}}$ & $\begin{array}{l}\text { Material: synthetical rubber; total length: } \\
460 \mathrm{~m} \text {; average diameter: } 21 \mathrm{~mm}\end{array}$ \\
\hline Diesel & 2801 & $42.6[8]$ & 10,138 & & \\
\hline Driver seat & $10 \mathrm{~kg}$ & $22.78^{\mathrm{b}}$ & 228 & 158 & Material: foamed PVC \\
\hline $\begin{array}{l}\text { Electrical } \\
\text { cables }\end{array}$ & $1.5 \mathrm{~kg}$ & $19.41^{\mathrm{b}}$ & 21 & 190 & Total length: $425 \mathrm{~m}$; average diameter: $1.4 \mathrm{~mm}$ \\
\hline Rubber covers & $10 \mathrm{~kg}$ & $27[6]$ & 270 & & \\
\hline Total & - & - & 76,245 & - & - \\
\hline
\end{tabular}

a Obtained from conducted cone calorimeter experiments prior to the full scale test.

${ }^{\mathrm{b}}$ Measured mean effective heat of combustion obtained from conducted cone calorimeter experiments.

${ }^{c}$ The heat release rate at $35 \mathrm{~kW} / \mathrm{m}^{2}$ was selected as an erroneous value at $50 \mathrm{~kW} / \mathrm{m}^{2}$ was measured during the cone calorimeter test.

Table 3

Basic technical information regarding the Rocket Boomer 322 drilling rig. This information was obtained from the manufacturer.

\begin{tabular}{ll}
\hline Length with boom & $12.4 \mathrm{~m}$ \\
Width & $2.19 \mathrm{~m}$ \\
Height & $2.95 \mathrm{~m}$ \\
Weight & $18,400 \mathrm{~kg}$ \\
Tyre dimensions & $13.00 \times 20$ PR 18 \\
\hline
\end{tabular}

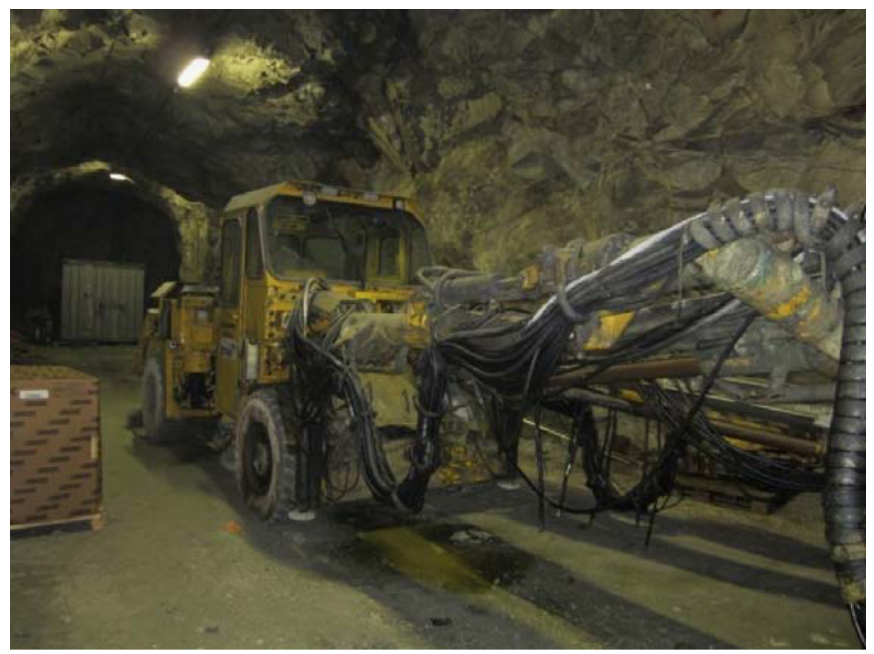

Fig. 2. The Rocket Boomer 322 drilling rig used in the full-scale fire experiment in Sala, Sweden. Photo: Andreas Fransson.

to an open pit. The non-active part is connected to an active part that goes down to level 90, see Fig. 3 .

The test site - i.e. the mine drift where the experiments took place - was approximately $150 \mathrm{~m}$ from the entrance to the mine and $40 \mathrm{~m}$ from the exhaust, see Fig. 3. The mine drift used as test site was approximately $100 \mathrm{~m}$ long. The difference in height between the entrance of the mine and the exhaust was virtually zero.

The test site had no fans installed in the immediate surroundings. Ventilation resources were therefore needed and a mobile fan of type Tempest model MGV L125, diesel powered, and a diameter of $1.25 \mathrm{~m}$ and with a primary air flow rate of $217.000 \mathrm{~m}^{3} / \mathrm{h}$ was therefore used to direct the flow in one direction. The location of the mobile fan is shown in Fig. 3.
There was only one exhaust on one side of the test site - all other mine drifts were dead ends on that side - allowing for all the smoke to be ventilated out through the single exhaust and thus allowing for heat release rate measurements on this side of the test site.

Before the fire experiments took place it was contemplated to seal the adjacent mine drifts with inflatable partitions in order to more effectively steer the ventilation flow to the exhaust. Performing CFD-simulations - using the FDS software [10] - it was concluded that partitions would not improve the flow of smoke to the exhaust, instead the partitions would increase the turbulence of the smoke. The main airflow became more or less as a bulk flow bypassing the short mine drifts from the fan towards the entrance. Thus the fire experiments were conducted without partitions in the adjacent mine drifts. Tests with the mobile fans prior to the fire tests confirmed this behavior.

The entrance of the mine created a large pressure loss for the fans due to the small exhaust area. The exhaust area can be estimated to be roughly about $12 \mathrm{~m}^{2}$. In Fig. 4 a photo of the exhaust area is shown. The entrance opening to the mine was much larger or about $50 \mathrm{~m}^{2}$.

In Fig. 5 the test site is shown more in detail, showing the approximate distances and the locations of measuring devices.

In Figs. 6 and 7 the position of the measuring devices at each vehicle is shown. A further description of the positions can also be found in Tables 5 and 6.

An earlier performed investigation on fire causes and fire behaviour with respect to vehicle fires in underground mines in Sweden [11] showed that full-scale fire experiments involving a diesel wheel loader and a drilling rig will have to be ignited using a diesel fire. This could be for example a pool fire underneath or in the engine compartment that is shielded and positioned close to larger amounts of combustibles such as tyres or hydraulic hoses. This would be necessary in order to achieve a fire growth and fire spread that eventually engulfs the entire vehicle. Thus a circular tray was placed underneath the fuel tank of each vehicle and it was located close to at least one tyre. The trays were filled with diesel fuel in order to simulate a pool fire caused by leaking diesel from the tank. The thickness of the fuel is of course exaggerated as it would be much thinner in a real situation. However, due to practical reasons and reasons mentioned earlier about fire spread this was found to be the best ignition method.

The door to the cab was opened and stayed open during the experiment. The two vehicles were not warmed up before the experiment. 
Table 4

Inventory of combustible components found on the Rocket Boomer 322 drilling rig.

\begin{tabular}{|c|c|c|c|c|c|}
\hline $\begin{array}{l}\text { Combustible } \\
\text { component }\end{array}$ & $\begin{array}{l}\text { Estimated amount } \\
\text { prior to test }\end{array}$ & $\begin{array}{l}\text { Effective heat of } \\
\text { combustion }[\mathrm{MJ} / \mathrm{kg}]\end{array}$ & $\begin{array}{l}\text { Estimated energy } \\
\text { content }[\mathrm{MJ}]\end{array}$ & $\begin{array}{l}\text { Mean heat release rate per } \\
\text { unit area }\left[\mathrm{kW} / \mathrm{m}^{2}\right]^{\mathrm{a}}\end{array}$ & Other \\
\hline Tyres & $155 \mathrm{~kg}$ & $27[6]$ & 4,185 & & $\begin{array}{l}\text { Dimensions: overall width } 0.35 \mathrm{~m} \text {; overall } \\
\text { diameter } 1.2 \mathrm{~m}\end{array}$ \\
\hline $\begin{array}{l}\text { Hydraulic oil in } \\
\text { tank }\end{array}$ & 3501 & $42.85[7]$ & 11,398 & & Type: Shell Tellus VG46 \\
\hline $\begin{array}{l}\text { Hydraulic oil in } \\
\text { hoses }\end{array}$ & 1501 & $42.85[7]$ & 4,885 & & Type: Shell Tellus VG46 \\
\hline Hydraulic hoses & $390 \mathrm{~kg}$ & $28.85^{\mathrm{b}}$ & 11,252 & $152^{\mathrm{C}}$ & $\begin{array}{l}\text { Material: synthetical rubber; total length: } \\
1000 \mathrm{~m} \text {; average diameter: } 22 \mathrm{~mm}\end{array}$ \\
\hline $\begin{array}{l}\text { Water hose } \\
\text { (rubber } \\
\text { material) }\end{array}$ & $40 \mathrm{~kg}$ & $28.85^{\mathrm{b}}$ & 1,154 & & $\begin{array}{l}\text { Total length: estimated at } 100 \mathrm{~m} \text {; diameter: } \\
35 \mathrm{~mm}\end{array}$ \\
\hline Diesel & 1001 & $42.6[8]$ & 3,621 & & \\
\hline Driver seat & $10 \mathrm{~kg}$ & $22.78^{\mathrm{b}}$ & 228 & 158 & Material: foamed PVC \\
\hline Electrical cables & $450 \mathrm{~kg}$ & $19.41^{\mathrm{b}}$ & 8,735 & 190 & Total length: $700 \mathrm{~m}$; Average diameter: $39 \mathrm{~mm}$ \\
\hline Plastic covers & $10 \mathrm{~kg}$ & $30[9]$ & 300 & & \\
\hline Total & - & - & 45,758 & - & - \\
\hline
\end{tabular}

a Obtained from conducted cone calorimeter experiments prior to the full scale tests.

${ }^{\mathrm{b}}$ Measured mean effective heat of combustion obtained from conducted cone calorimeter experiments.

${ }^{c}$ The heat release rate at $35 \mathrm{~kW} / \mathrm{m}^{2}$ was selected as an erroneous value at $50 \mathrm{~kW} / \mathrm{m}^{2}$ was received.

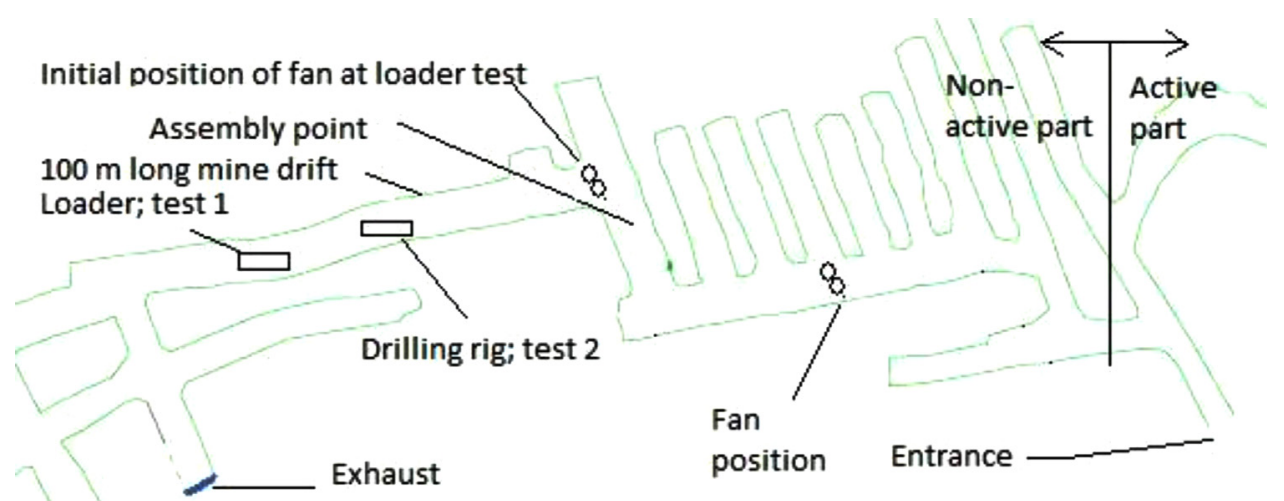

Fig. 3. Plan of the level 55 which is today a non-active part mine. The entrance to the mine is indicated on the right hand side of the sketch and the exhaust on the left hand side.

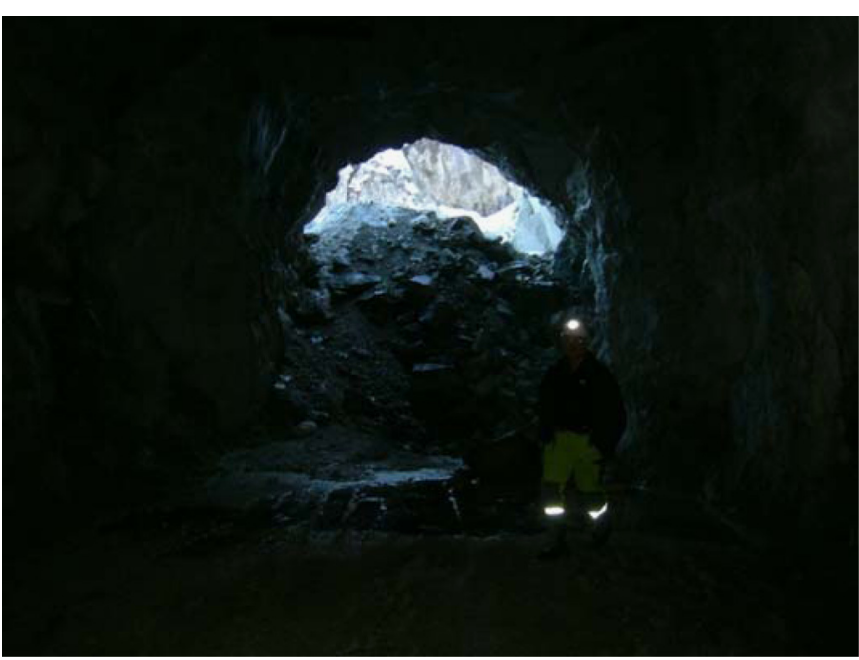

Fig. 4. A photo of the exhaust area of the mine.

The ignition of the pool fire underneath the tank took placeusing pieces of fiber board soaked in diesel.

A video camera was used in each experiment in order to record the ignition of various fuel components, flame spread, fire development etc. The video footage could for example be used when relating a certain change in the heat release rate to the visual appearance at the scene of the fire.

\subsection{Test 1 with a wheel loader}

The front of wheel loader was placed $30 \mathrm{~m}$ from the measuring station in the mining drift. The fuel tank was emptied to $90 \mathrm{l}$, the remaining $190 \mathrm{l}$ of diesel fuel was emptied into a circular tray with a diameter of $1.1 \mathrm{~m}$. The fuel surface was even with the top of the rim.

The fan was started 1 min before ignition. The average longitudinal ventilation velocity at the measuring station was close to zero prior to the ignition and the start up of the fan, $0.2 \mathrm{~m} / \mathrm{s}$ at the time of ignition and $1.6 \mathrm{~m} / \mathrm{s}$ at the maximum heat release rate (the ventilation velocity was measured approximately $30 \mathrm{~m}$ downstream of the fire). A certain delay in the measured ventilation velocity at the measuring station from the mobile fan can be attributed to the distance between the fan and the measuring station. The average ventilation velocity for the initial $12 \mathrm{~min}$ of measurements is found in Fig. 8; the measurements were initiated 2 min before ignition.

Approximately $10 \mathrm{~min}$ after ignition the backlayering smoke reached the fan and the fan had to be geared down temporarily (was geared up again a few minutes later) and moved approximately 


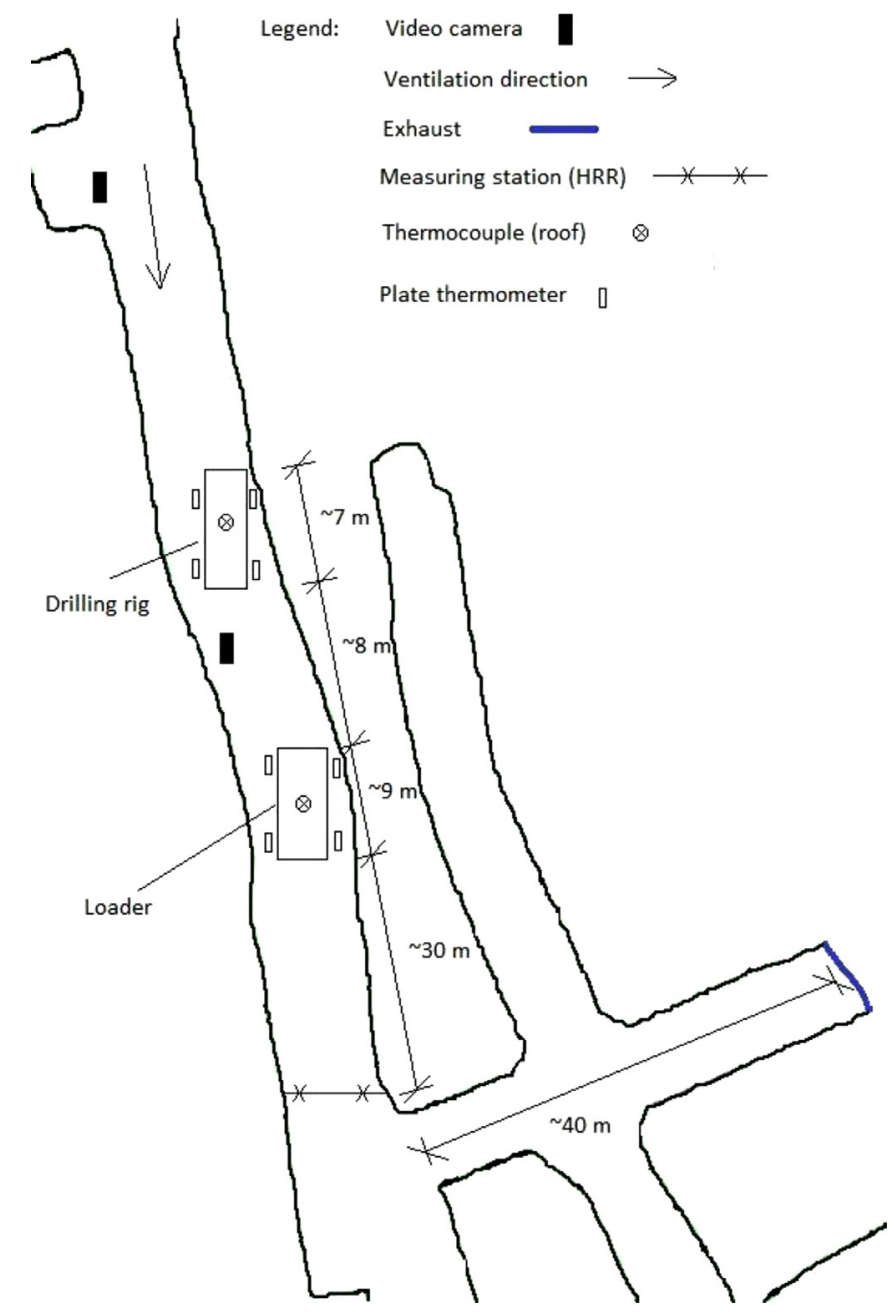

Fig. 5. A plan view of the test site (not to scale).

$50 \mathrm{~m}$ further away from the fire in order to more easily establish a distinct pressure and flow situation.

\subsection{Test 2 with a drilling rig}

The front end of the drilling rig was placed about $17 \mathrm{~m}$ from the rear end of the remains of the wheel loader from test 1 . This means the front end of the drilling rig was now $47 \mathrm{~m}$ from the measuring station. Before the test the fuel tank was emptied to $40 \mathrm{l}$, the remaining $60 \mathrm{l}$ of diesel fuel was emptied into a circular tray with a diameter of $1 \mathrm{~m}$. The free distance between the top of the rim and the fuel surface was $120 \mathrm{~mm}$.

The fan was started approximately $20 \mathrm{~min}$ before ignition. The average longitudinal ventilation velocity was $1.3 \mathrm{~m} / \mathrm{s}$ at ignition and $2.5 \mathrm{~m} / \mathrm{s}$ at the maximum heat release rate (the ventilation velocity was measured approximately $50 \mathrm{~m}$ downstream of the

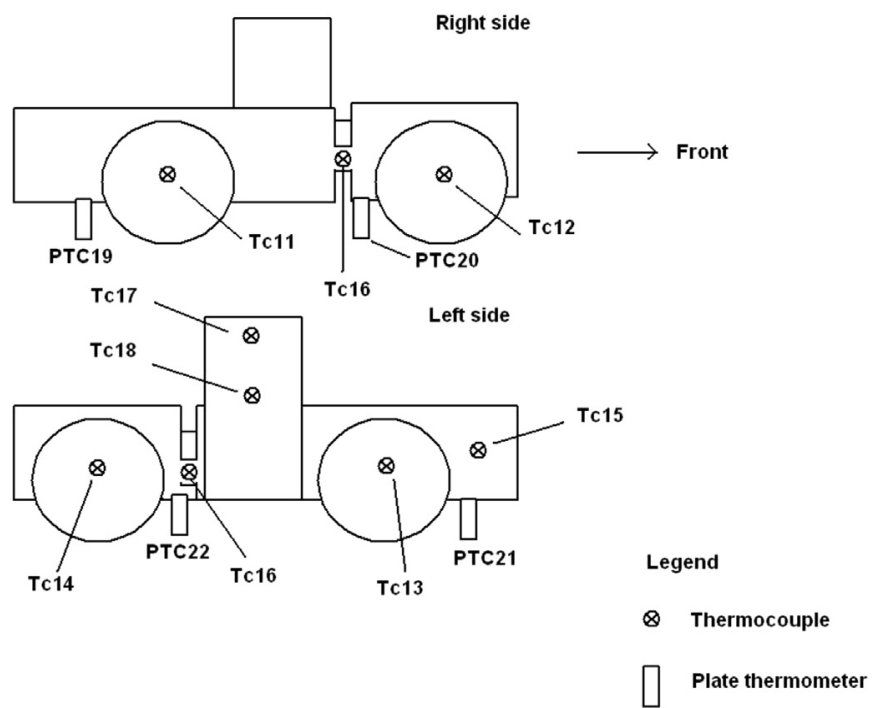

Fig. 6. The position of the thermocouples and plate thermometers on the wheel loader.

\section{Measurement and calculation procedure}

The heat release rate in the fire experiments was determined with aid of the oxygen calorimetry concept [5]. This means that the mass flow rate, gas concentrations and temperatures at certain heights at the far end of the mine drift and downstream of the fire source are used to calculate the heat release rate during the test. At the measuring station downstream the fire numerous instruments were mounted over the cross-section. In the first test the measuring station was at a distance of $+30 \mathrm{~m}$ (plus means downstream of the fire) from the front side of the wheel loader. For the drilling rig this distance was $+47 \mathrm{~m}$. The measurements used to determine the heat release rate were thermocouples, pressure probes for determining the velocity and gas instruments to measure the oxygen, carbon monoxide and carbon dioxide content in the hot fire gases. The instrument layout is shown in Fig. 10.

The calculation of the heat release rate applied here is based on method presented by Ingason [12] using many thermocouples distributed over the actual cross-section and only single point for measuring gas concentrations. The environment in a mine drift is generally very harsh for sensitive instruments - with high humidity etc - making this method attractive for HRR measurements in an underground mine. Other advantages with the method are that we can determine very large HRR and we do not need to know the average gas concentration in the applicable cross-section, instead the average value is calculated using temperature and oxygen readings - where only one or two readings may be sufficient over the cross-section.

The heat release rate - using mass flow rate, gas concentration and temperature data - can be calculated using the following equation assuming that the local gas temperature and the local gas concentration correlate through the average values over the cross-section [12]:

$\dot{Q}=\frac{13,100 \times \rho_{0} \times u_{0} \times A \times\left(M_{\mathrm{O}_{2}} / M_{a}\right) \times\left(1-X_{\mathrm{H}_{2} \mathrm{O}, 0}\right)}{\left(0.1 / X_{\mathrm{O}_{2}, 0}\right)+\left[\left(1-X_{\mathrm{O}_{2}, \text { avg }}\right) \times\left(X_{\mathrm{O}_{2}, \text { avg }} /\left(1-X_{\mathrm{CO}_{2}, \text { avg }}\right)\right) /\left(X_{\mathrm{O}_{2}, 0}-\left(X_{\mathrm{O}_{2}, \text { avg }} \times\left(\left(1-X_{\mathrm{CO}_{2}, 0}\right) /\left(1-X_{\mathrm{CO}_{2}, \text { avg }}\right)\right)\right)\right]\right.}$

center of the fire). The average ventilation velocity for the initial 24 min of measurements is found in Fig. 9; the measurements were initiated $2 \mathrm{~min}$ before ignition.

A distinct pressure and flow situation was successfully established during the entire experiment, using the fan position further away from the fire.
The molecular weight of oxygen - $M_{\mathrm{O}_{2}}$ - was set to $32 \mathrm{~g} / \mathrm{mol}$. The molecular weight of air $-M_{a}-$ was set to $28.95 \mathrm{~g} / \mathrm{mol}$. The mole fraction of water in the ambient air $-X_{\mathrm{H}_{2} \mathrm{O}, 0}$ - was set to 0.005 . The mole fraction of oxygen in the ambient air $-X_{\mathrm{O}_{2}, 0}-$ was set to 0.2095 . The mole fraction of carbon dioxide in the ambient air - $X_{\mathrm{CO}_{2}, 0}$ - was set to 0.00033 . 


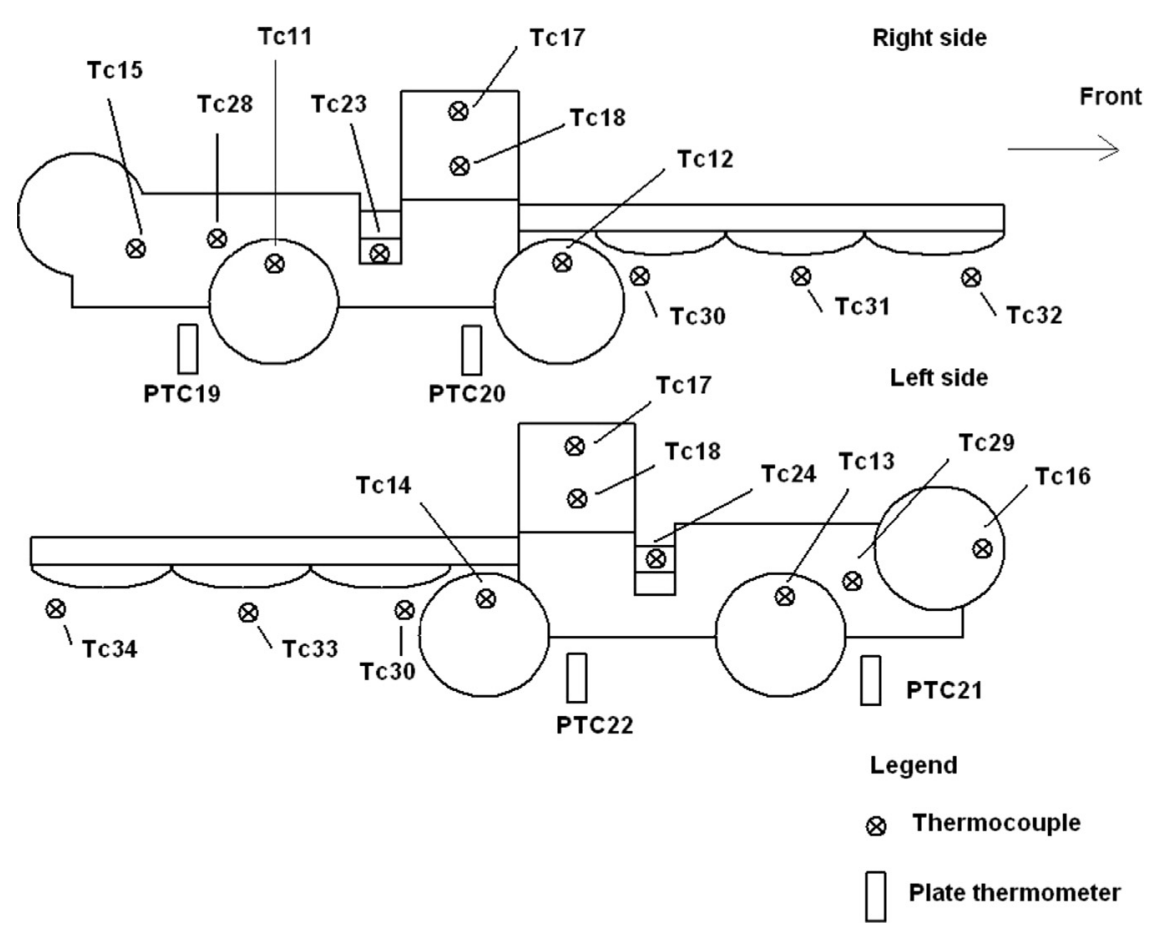

Fig. 7. The position of the thermocouples and plate thermometers on the drilling rig.

Table 5

Description of the thermocouples and plate thermometers at the wheel loader.

\begin{tabular}{|c|c|c|}
\hline Id \# & Specification of instrument ( $\mathrm{mm})$ & Position \\
\hline Tc11 & 0.5 & Tyre; right, rear. Positioned at the rim \\
\hline Tc12 & 0.5 & Tyre; right, forward. Positioned at the rim \\
\hline Tc13 & 0.5 & Tyre; left, rear. Positioned at the rim \\
\hline Tc14 & 0.5 & Tyre; left, forward. Positioned at the rim \\
\hline Tc15 & 0.5 & On bundle of hydraulic hoses in the rear, left side \\
\hline Tc16 & 0.5 & On bundle of hydraulic hoses at the waist \\
\hline Tc17 & 0.5 & Interior of cab, at the ceiling \\
\hline Tc18 & 0.5 & Interior of cab, on the driver seat \\
\hline PTC19 & & $\begin{array}{l}\text { Tyre, right, rear. In line with the rear edge of the tyre; facing the vehicle; } 0.5 \mathrm{~m} \text { from the tyre; } \\
0.4 \mathrm{~m} \text { from the ground to the centre of thermometer }\end{array}$ \\
\hline PTC20 & & $\begin{array}{l}\text { Tyre, right, forward. In line with the rear edge of the tyre; facing the rear of the vehicle; } \\
0.5 \mathrm{~m} \text { from the tyre; } 0.44 \mathrm{~m} \text { from the ground to the centre of thermometer }\end{array}$ \\
\hline PTC21 & & $\begin{array}{l}\text { Tyre, left, rear. In line with the rear edge of the tyre; facing the vehicle; } 0.43 \mathrm{~m} \text { from the tyre; } \\
0.4 \mathrm{~m} \text { from the ground to the centre of thermometer }\end{array}$ \\
\hline PTC22 & & $\begin{array}{l}\text { Tyre, left, forward. In line with the rear edge of the tyre; facing the rear of the vehicle; } \\
0.5 \mathrm{~m} \text { from the tyre; } 0.44 \mathrm{~m} \text { from the ground to the centre of thermometer }\end{array}$ \\
\hline Tc23 & 0.5 & In the ceiling above the wheel loader \\
\hline Тc24 & 1.5 & In the ceiling above the wheel loader \\
\hline
\end{tabular}

In Eq. (1) it is assumed that $13,100 \mathrm{~kJ} / \mathrm{kg}$ (E-factor) is released per $\mathrm{kg}$ of oxygen consumed and that air mass flow rate of combustion gases equals the ambient air mass flow rate. The integrated HRR over the measuring period was compared to the total energy content of each vehicle given in Tables 2 and 4 minus the remains from the each test. This procedure gives an indication of the accuracy of the HRR calculation method used here.

The observation of a correlation between the local gas temperature and local gas concentrations to the average value for the actual cross-section is based upon the original work of Newman [13], who tested the correlation for different types of fuels in a test gallery representing a duct or a mine drift. Eq. (1) requires that the heat release rate measuring station is positioned outside the reaction zone of the fire and that a uni-directional ventilation flow past the measuring station is secured during the entire experiment. In the case when it is only possible to use one measuring point for the gas, as in the present case, it is recommended to use more than one temperature measuring point in order to increase the reliability of the output data and the dependence on one single measuring point.

It has been shown by Ingason [12], that it is possible to relate multiple gas temperatures measurements in a single tunnel cross section to the average gas concentrations in a longitudinal tunnel flow, see Eqs. (2)-(4). The average concentration of oxygen and carbon dioxide was calculated using the following equations [12]:

$$
\begin{aligned}
& X_{\mathrm{O}_{2}, a v g}=X_{\mathrm{O}_{2}, 0}-\frac{\left(X_{\mathrm{O}_{2}, 0}-X_{\mathrm{O}_{2}, h}\right) \sum_{i=1}^{N_{T}}\left(T_{i}-T_{0}\right)}{\left(T_{h}-T_{0}\right)} N_{T} \\
& X_{\mathrm{CO}_{2}, a v g}=X_{\mathrm{CO}_{2}, 0}-\frac{\left(X_{\mathrm{CO}_{2}, 0}-X_{\mathrm{CO}_{2}, h}\right) \sum_{i=1}^{N_{T}}\left(T_{i}-T_{0}\right)}{\left(T_{h}-T_{0}\right)} N_{T}
\end{aligned}
$$


Table 6

Description of the thermocouples and plate thermometers at the drilling rig.

\begin{tabular}{|c|c|c|}
\hline Id \# & Specification of instrument (mm) & Position \\
\hline Tc11 & 0.5 & Tyre; right, rear. On the upper edge of the tyre \\
\hline Tc12 & 0.5 & Tyre; right, forward. On the upper edge of the tyre \\
\hline Tc13 & 0.5 & Tyre; left, rear. On the upper edge of the tyre \\
\hline Tc14 & 0.5 & Tyre; left, forward. On the upper edge of the tyre \\
\hline Tc15 & 0.5 & Bundle of hydraulic hoses in the rear, right side \\
\hline Tc16 & 0.5 & On the rear of the cable reel; left side, rear part \\
\hline Tc17 & 0.5 & Interior of cab, at the ceiling \\
\hline Tc18 & 0.5 & Interior of cab, on the driver seat \\
\hline PTC19 & & $\begin{array}{l}\text { Tyre; right, rear. In line with the rear edge of the tyre; facing the vehicle; } 0.5 \mathrm{~m} \text { from the tyre; } \\
0.4 \mathrm{~m} \text { from the ground to the centre of thermometer }\end{array}$ \\
\hline PTC20 & & $\begin{array}{l}\text { Tyre; right, forward. In line with the rear edge of the tyre; facing the rear of the vehicle; } 0.5 \mathrm{~m} \text { from the tyre; } \\
0.4 \mathrm{~m} \text { from the ground to the centre of thermometer }\end{array}$ \\
\hline PTC21 & & $\begin{array}{l}\text { Tyre; left, rear. In line with the rear edge of the tyre; facing the vehicle; } 0.5 \mathrm{~m} \text { from the tyre; } \\
0.4 \mathrm{~m} \text { from the ground to the centre of thermometer }\end{array}$ \\
\hline PTC22 & & $\begin{array}{l}\text { Tyre; left, forward. In line with the rear edge of the tyre; facing the rear of the vehicle; } 0.5 \mathrm{~m} \text { from the tyre; } \\
0.4 \mathrm{~m} \text { from the ground to the centre of thermometer }\end{array}$ \\
\hline Tc23 & 0.5 & On a bundle of hydraulic hoses; at the lower part of the waist; right hand side \\
\hline Tc24 & 1.5 & On a bundle of hydraulic hoses; at the upper part of the waist; left hand side \\
\hline Tc28 & 0.5 & Inside the rear, right wheelhouse; in the rear, upper part of the wheelhouse; attached to hydraulic hoses \\
\hline Tc29 & 0.5 & Inside the rear, left wheelhouse; in the rear, upper part of the wheelhouse; attached to hydraulic hoses \\
\hline Tc30 & 0.5 & On bundle of hydraulic hoses; between the forward wheels \\
\hline Tc31 & 0.5 & On bundle of hydraulic hoses; middle of the boom; right side \\
\hline Tc32 & 0.5 & On bundle of hydraulic hoses; forward of the boom; right side \\
\hline Tc33 & 0.5 & On bundle of hydraulic hoses; middle of the boom; left side \\
\hline Tc34 & 0.5 & On bundle of hydraulic hoses; forward of the boom; left side \\
\hline Tc35 & 1.5 & In the ceiling above the drilling rig \\
\hline Tc36 & 0.5 & In the ceiling above the drilling rig \\
\hline
\end{tabular}

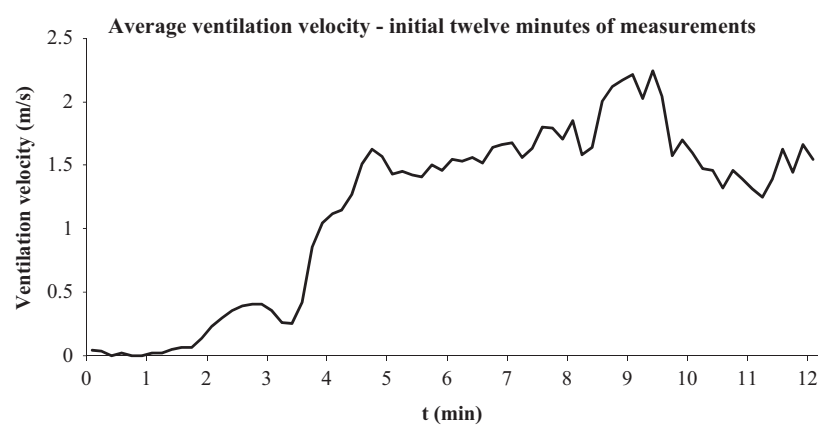

Fig. 8. The average longitudinal ventilation velocity at the measuring station during the initial $12 \mathrm{~min}$ of measurements at measuring station $+30 \mathrm{~m}$.

In the following calculations the average concentration of carbon monoxide was calculated in an analogous manner:

$X_{\mathrm{CO}, a v g}=X_{\mathrm{CO}, 0}-\frac{\left(X_{\mathrm{CO}, 0}-X_{\mathrm{CO}, h}\right) \sum_{i=1}^{N_{T}}\left(T_{i}-T_{0}\right)}{\left(T_{h}-T_{0}\right)}$

The mole fraction of carbon monoxide in the ambient air $X_{\mathrm{CO}, 0}$ - was set to 0.00005 as the mole fraction of carbon monoxide was measured approximately at this level in the mine drift before the ignition took place.

The gas temperatures were measured every $10 \mathrm{~s}$ by a type $\mathrm{K}$ thermocouple of $0.5 \mathrm{~mm}$.

The cold gas velocity in Eq. (1) is calculated using the following equation:

$u_{0}=u_{a v g} \times\left(\frac{T_{0}}{T_{a v g}}\right)$

where the average longitudinal velocity and temperature in the mine drift are calculated using the average values of the velocity probes and thermocouples at the heat release rate measuring station (see Fig. 10). An average temperature of the three thermocouples at the same level as the gas analysis was first calculated

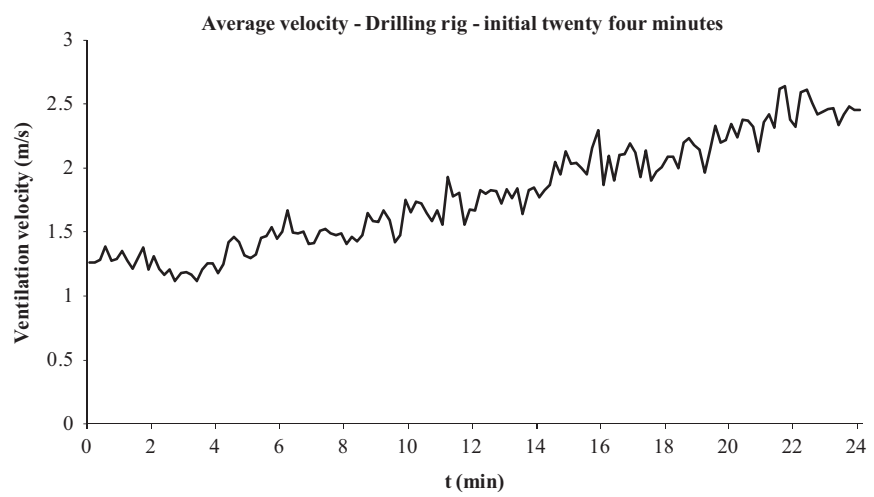

Fig. 9. The average longitudinal ventilation velocity during the initial $24 \mathrm{~min}$ of measurements at measuring station $+47 \mathrm{~m}$.

and then added to the other three temperature readings in order to obtain an average value of the entire cross-section.

Ingason and Lönnermark [4] have used Eqs. (1)-(3) in order to determine the heat release rate in a series of large scale tunnel fire tests.

The heat release rate was measured at the end of the mine drift (see Fig. 4 for the position of the measuring devices) in order to ensure that the measuring station was outside the reaction zone of the fire. The site was also chosen in order to make sure that all the fire gases would directly pass the site without entering other parts of the mine. As can be seen in Fig. 10, the heat release rate was measured using six thermocouples, four velocity probes and one gas analysis $\left(\mathrm{O}_{2}, \mathrm{CO}, \mathrm{CO}_{2}\right)$ mounted on pillars positioned downstream of the fire. The dimensions of the mine drift where the heat release rate took place were $6.3 \mathrm{~m}$ (height) by $8.5 \mathrm{~m}$ (width). The dimensions of the mine drift where the wheel loader and the drilling rig were placed were $6.8 \mathrm{~m}$ (height) by $8.7 \mathrm{~m}$ (width).

The temperature above each vehicle was measured with thermocouples attached to the ceiling above the vehicle in question. 

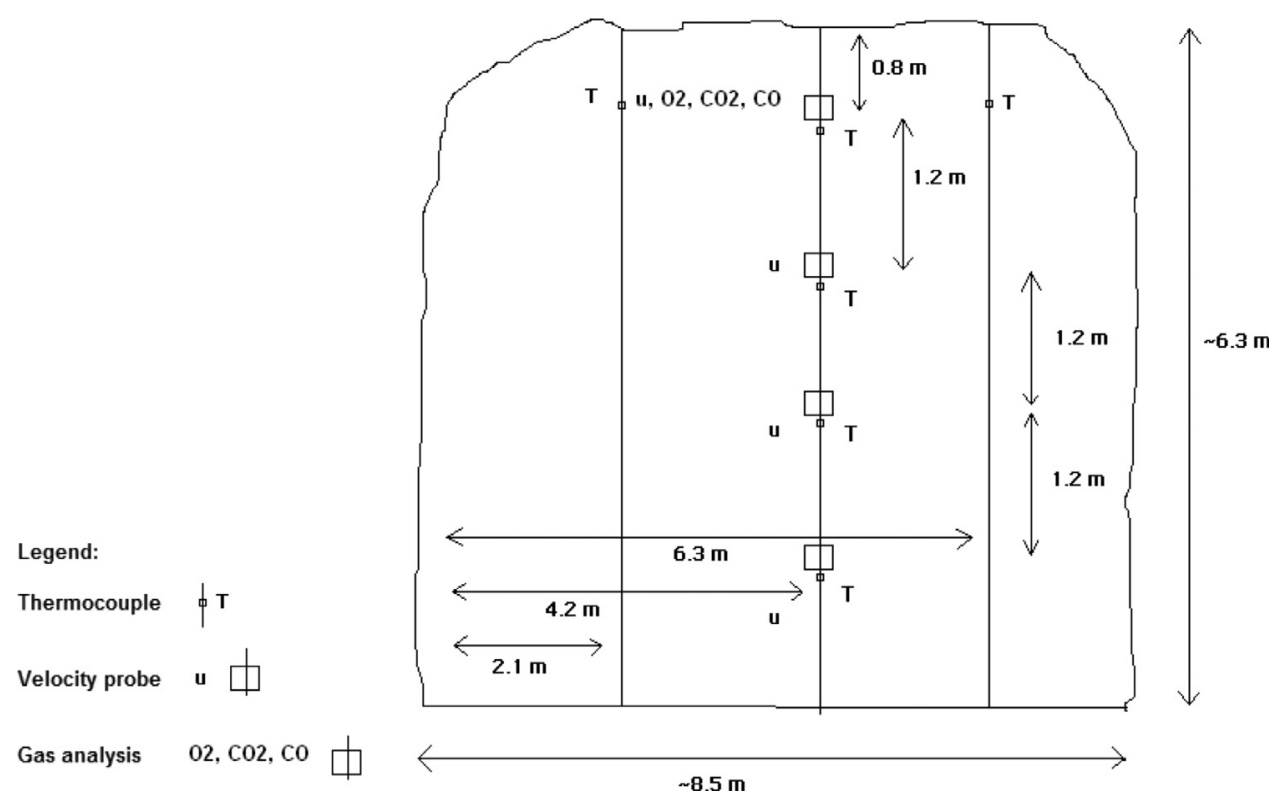

Fig. 10. The measuring station $+30 \mathrm{~m}$ and $+47 \mathrm{~m}$, respectively, for calculation of the heat release rate using gas concentrations $\left(\mathrm{O}_{2}\right.$, $\mathrm{CO}_{2}$, $\left.\mathrm{CO}\right)$, velocity $(u)$ and gas temperatures $(T)$.

The velocity at certain heights in the mine drift was determined by bi-directional probes. A differential pressure transmitter was used in the experiments, model: FCO332-3W ( $\pm 50 \mathrm{~Pa})$.

The velocity at each bi-directional probe was determined using the following equation:

$u_{\text {probe }}=\frac{1}{k(R e)} \sqrt{\frac{2 \times \Delta p \times T}{\rho_{0} \times T_{0}}}$

The diameter of the probes used was $16 \mathrm{~mm}$ and the probe length was $32 \mathrm{~mm}$.

The correction coefficient $-k(R e)-$ is found to hold as a constant value of 1.08 for Reynolds number larger than 2000 [14]. In the two conducted fire experiments the Reynolds number was in the range of $1400-2700$, implying that the correction coefficient is equal to 1.08 or approximately equal to 1.08 .

The oxygen concentration was measured using an M\&C PMA10 set for the interval $0-30 \%$. The carbon monoxide and the carbon dioxide were measured using a Rosemount Binos 100 in the case of the wheel loader ( $\left.\mathrm{CO}: 0-10 \% ; \mathrm{CO}_{2}: 0-30 \%\right)$ and a Siemens Ultramat $22 \mathrm{P}$ in the case of the drilling rig (CO: $\left.0-3 \% ; \mathrm{CO}_{2}: 0-10 \%\right)$. The thermocouples, the differential pressure transmitter, the gas analysers and velocity probes were connected to a 20-channel Solartron 5000 IMP logger. The data was recorded on a laptop computer at a rate of about one scan per $10 \mathrm{~s}$.

The incident radiation heat flux at the tyres of the vehicles was measured using plate thermometers. The incident radiation heat flux was determined using the following equation by Ingason and Wickström [15] developed for the plate thermometer:

$q^{\prime \prime}{ }_{i n c}=\frac{\varepsilon_{P T} \times \sigma \times T_{P T}^{4}+\left(h_{P T}+K_{\text {cond }}\right) \times\left(T_{P T}-T_{0}\right)+\rho_{s t} \times c_{s t} \times \delta \times \Delta T_{P T} / \Delta t}{\varepsilon_{P T}}$

where the surface emissivity of the plate thermometer $-\varepsilon_{P T}-$ was set to 0.8 , the convective heat transfer coefficient $-h_{P T}-$ was set to $10 \mathrm{~W} / \mathrm{m}^{2} \mathrm{~K}$ [15], the conduction correction factor $-K_{\text {cond }}$ - was set to $22 \mathrm{~W} / \mathrm{m}^{2} \mathrm{~K}$ [16], the density of steel $-\rho_{s t}$ - was set to $8100 \mathrm{~kg} / \mathrm{m}^{3}$, the specific heat capacity of steel $-c_{s t}-$ was set to $460 \mathrm{~J} / \mathrm{kg} \mathrm{K}$ and the thickness of steel plate $-\delta-$ was set to $0.0007 \mathrm{~m}$ [15].

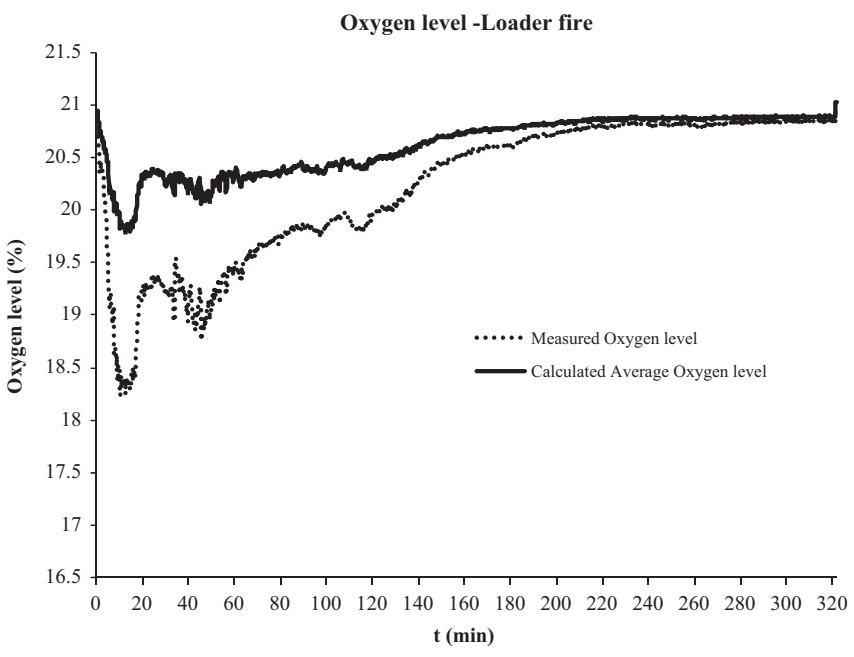

Fig. 11. The measured oxygen level and the calculated average oxygen level at measuring station $+30 \mathrm{~m}$.

\section{Results}

An inventory of the individual combustible components of the vehicle were obtained, see Tables 2 and 4, and by adding up the individual energy contents it was possible to compare it to the integrated HRR curve yielding the total energy content from the experiments. As a final part of the method, an uncertainty analysis of the HRR measurements was carried out in order to investigate accuracy of the results. The uncertainty analysis is found at the end of this section.

\subsection{Test 1 with wheel loader}

The heat release rate will be dependent upon the average concentration of the oxygen and carbon dioxide and the cold gas velocity, where the cold gas velocity in return will be dependent upon the average ventilation velocity and average gas temperature.

In Fig. 11 the measured oxygen level at the ceiling level and the calculated average oxygen level for the wheel loader fire is displayed. As can be seen the calculated values follow the fluctuations of the 
measured values and the measured oxygen level is generally $0.5-1.0 \%$ lower than the calculated level, which could be expected.

A lowest oxygen level was registered at $18.2 \%$. A highest carbon monoxide level was registered at $0.09 \%$ and the highest carbon dioxide level at $1.87 \%$ occurring at the time of the maximum heat release rate, see Fig. 12 for the variation of the carbon monoxide and carbon dioxide level. Due to the high oxygen level and fairly low highest level of the carbon monoxide, the fire was not ventilation controlled. As can be seen in Fig. 12 the measured CO level curve has a jagged appearance, which is due to that the used scale is closer to the resolution limit. It appears that the CO measurements functioned well for the first $20 \mathrm{~min}$, but after that time interval some kind of disturbance seems to have occurred as the $\mathrm{CO}$ value remain fairly constant as opposed to the calculated $\mathrm{CO}$ value. Therefore the $\mathrm{CO}$ values after $20 \mathrm{~min}$ were not used in the ensuing heat release rate calculations. When investigating the error introduced by the lack of $\mathrm{CO}$ values it was found that the error was estimated to approximately $<1.0 \%$; i.e. $<1.0 \%$ lower than the calculated (as the E-factor will decrease with an incomplete combustion).

The average ventilation velocity before ignition was in the interval $0.02-0.4 \mathrm{~m} / \mathrm{s}$, which was in an interval lower than desired. The average ventilation velocity at the time of ignition was measured at $0.3 \mathrm{~m} / \mathrm{s}$. The average ventilation velocity between ignition and the time of maximum heat release rate was in the interval $0.3-2.2 \mathrm{~m} / \mathrm{s}$, see Fig. 13 for the average velocity at the measuring station from ignition and onwards. See Fig. 8 for the first $12 \mathrm{~min}$ into the test. The maximum average ventilation velocity at $2.2 \mathrm{~m} / \mathrm{s}$ occurred after approximately 7 min which is the time just before the mobile fan was geared down and moved to the position further away from the fire.

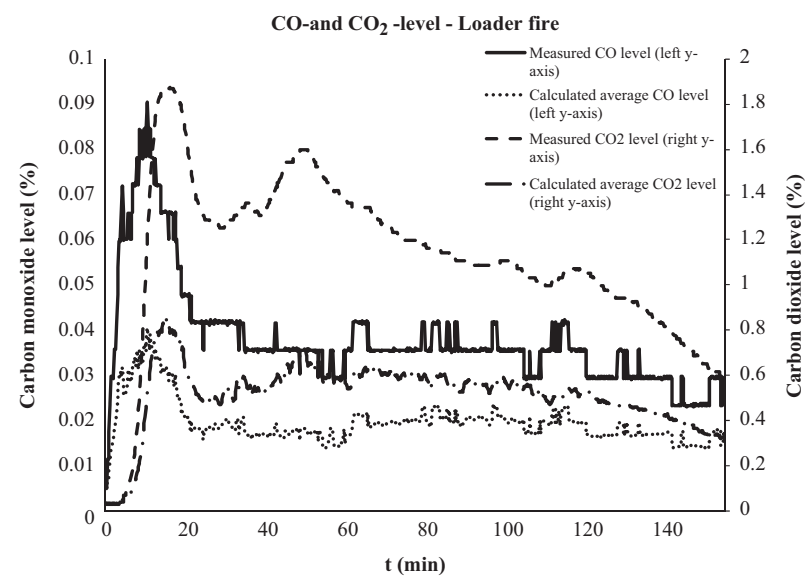

Fig. 12. The measured carbon monoxide and carbon dioxide level and the calculated average carbon monoxide and carbon dioxide level at measuring station $+47 \mathrm{~m}$.

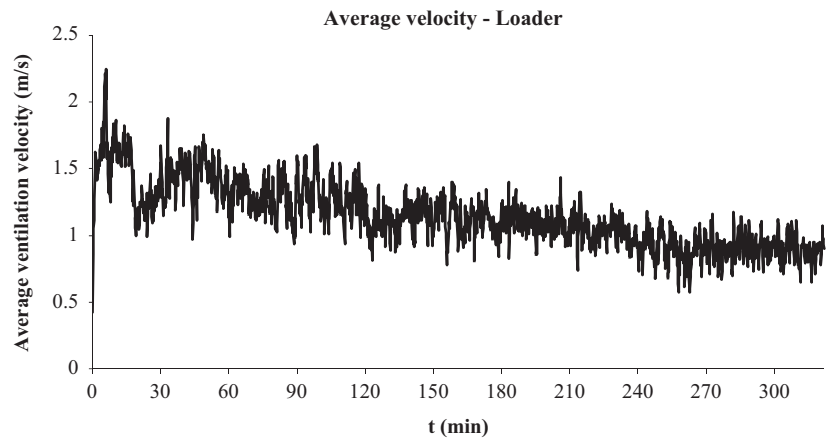

Fig. 13. The average ventilation velocity during the entire tests at measuring station $+30 \mathrm{~m}$.
Regarding the average gas temperature at the measuring station, the maximum gas temperature, $74^{\circ} \mathrm{C}$, occurs after approximately $11 \mathrm{~min}$, which is the same time as the occurrence of the maximum heat release rate. This latter observation is expected as the average oxygen and carbon dioxide concentration correlates with the average gas temperature at the measuring station. The heat release rate results from these tests are shown in Fig. 15. When observing the appearance of the graphs found in Fig. 15 and the average gas temperature in Fig. 14 the appearance is found to be similar. This behavior is expected for this type of measurements as the velocity and the gas temperature are indicators of the total mass flow rate of air.

Due to the distance between the wheel loader and the measuring station there is a time delay with respect to the heat release rate measurements depending upon the longitudinal ventilation velocity and the distance. Calculating and summing up the progress of the fire gases for each time step with the aid of the calculated average ventilation velocity at the measuring station in the mine drift, the following time delay was received (and the corresponding heat release rate curve and other curves originating from the measuring station was adjusted accordingly): $80 \mathrm{~s}$.

The maximum heat release rate from the experiment was 15.9 MW. The maximum heat release rate was attained approximately 11 min after ignition.

When examining the remains after the experiment it was found that only the rear tyres had participated in the fire and the front tyres were remained intact. Furthermore, the hydraulic hoses from the waist and forward and in some parts of the section behind the rear tyres also remained intact. The interior of the cab had participated fully in the fire and the combustible material being consumed.

The energy content of the combustible materials consumed in the fire was determined by integrating the measured heat release

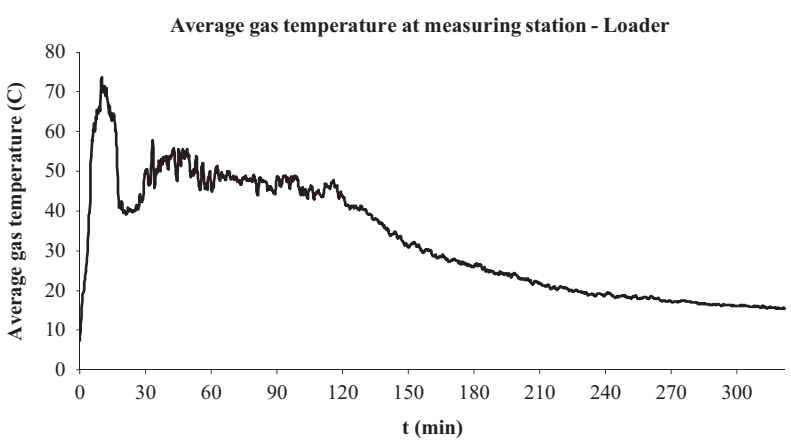

Fig. 14. The average gas temperature at the measuring station in the case of the wheel loader fire at measuring station $+30 \mathrm{~m}$.

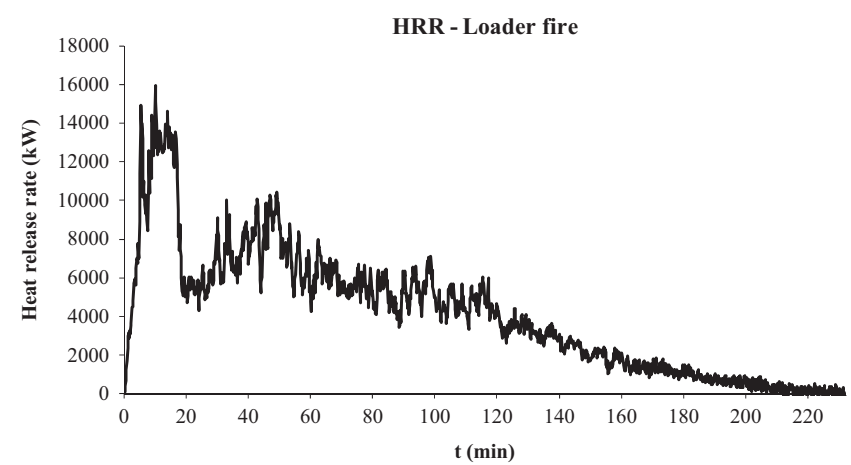

Fig. 15. The calculated heat release rate of the wheel loader. 
rate curve. The total integrated energy content using the measured heat release rate was $57 \mathrm{GJ}$. When summing up the energy contents of the materials participating in the fire and found in Table 2, an energy content of $50.5 \mathrm{GJ}$ was obtained (if everything would have burned the total was estimated to be $76.2 \mathrm{GJ}$ ). Be aware that only 2801 of diesel, the cab (driver seat and rubber covers), the hydraulic oil in the tank, the two rear tyres, estimated $50 \%$ of the hydraulic hoses, the hydraulic oil in the hoses and the electrical cables were assumed to have participated in the fire. The estimated energy content using an inventory was thus approximately $13 \%$ larger than the calculated energy content where the measured heat release rate curve was integrated. This difference is most likely due to the uncertainties when primarily estimating the amount of combustibles available and to some extent the amount of combustibles consumed in the fire Fig. 16.

\subsection{Test 2 with drilling rig}

In Fig. 17 the measured oxygen level at the ceiling level and the calculated average oxygen level for the drilling rig fire is displayed. Same as for the case of the wheel loader fire it can be seen that the calculated values follow the fluctuations of the measured values and that the measured oxygen level is generally about $1.0 \%$ lower than the calculated level.

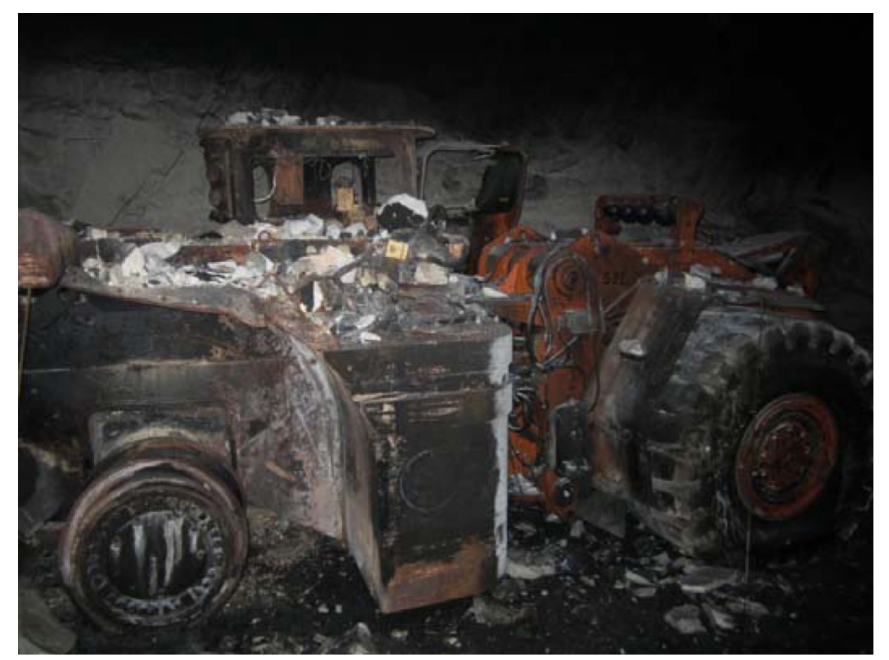

Fig. 16. The wheel loader after the fire experiment. Photo: Andreas Fransson.

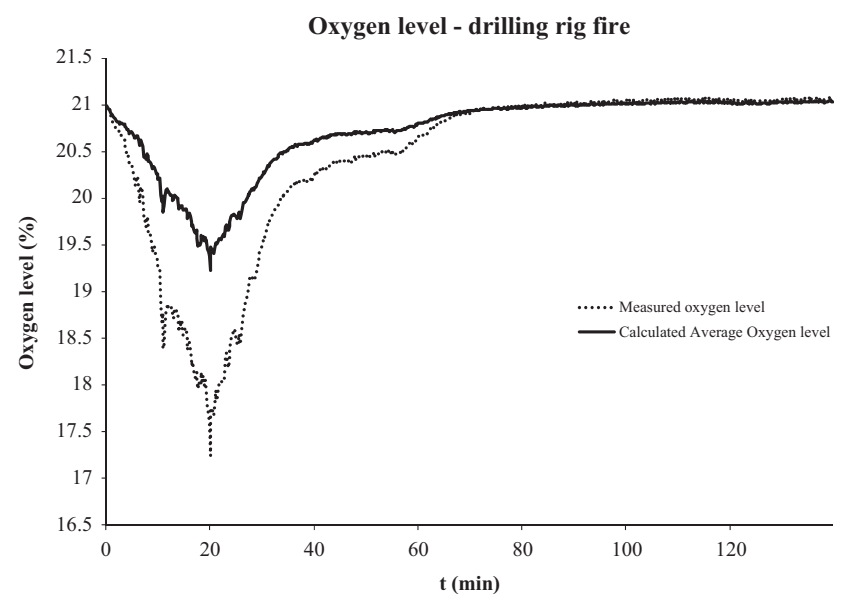

Fig. 17. The measured oxygen level and the calculated average oxygen level at measuring station $+47 \mathrm{~m}$.
A minimum oxygen level was registered at $17.2 \%$. A highest carbon dioxide level at $2.37 \%$ occurred at the time of the maximum heat release rate. See Fig. 18 for the measured values of carbon dioxide. Unfortunately a measuring error occurred with respect to the carbon monoxide measurements and no graph can therefore be displayed. The error due to the lack of carbon monoxide values was estimated to approximately $<1.5 \%$; i.e. $<1.5 \%$ lower than the calculated (as the E-factor will decrease with an incomplete combustion).

The average ventilation velocity before ignition was in the interval $1.2-1.4 \mathrm{~m} / \mathrm{s}$. The average ventilation velocity at the time of ignition was measured at $1.3 \mathrm{~m} / \mathrm{s}$. The average ventilation velocity between ignition and the time of maximum heat release rate was in the interval $1.1-2.6 \mathrm{~m} / \mathrm{s}$, the maximum value occurring at the time of the maximum heat release rate (Fig. 19).

The maximum average gas temperature at the measuring station, $93^{\circ} \mathrm{C}$, occurs after approximately $21 \mathrm{~min}$, which is the same time as the occurrence of the maximum heat release rate. The heat release rate results from these tests are shown in Fig. 21.

When comparing the average gas temperature in Fig. 20 and the heat release rate curve in Fig. 21 it can be seen that the average gas temperature at the measuring station correlates well with the measured heat release rate.

The time delay with respect to the heat release rate measurements was found to be $80 \mathrm{~s}$ and the corresponding heat release rate curve was adjusted accordingly.

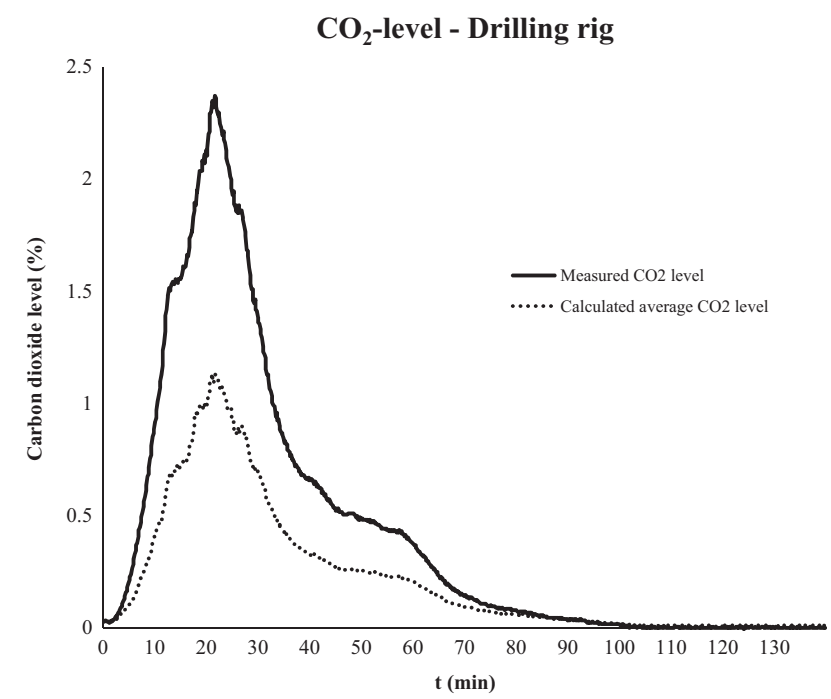

Fig. 18. The measured carbon dioxide level and calculated average carbon dioxide level at measuring station $+47 \mathrm{~m}$.

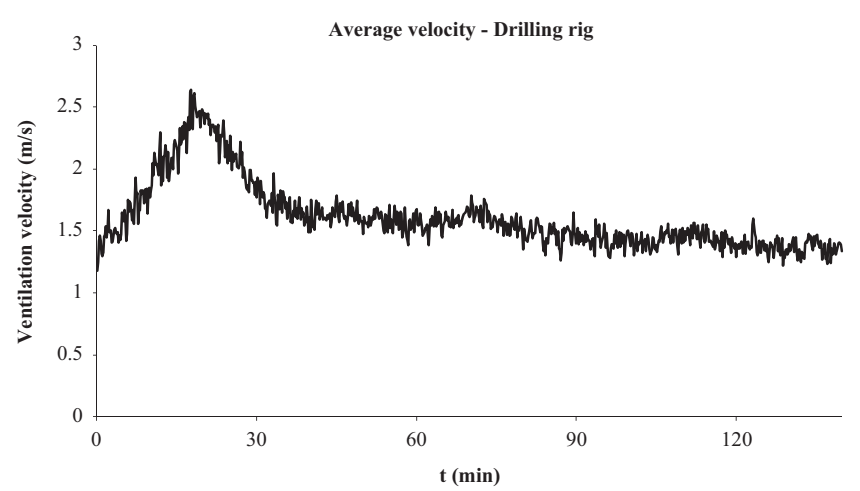

Fig. 19. The average ventilation velocity during the entire test at the measuring station $(+47 \mathrm{~m})$. 


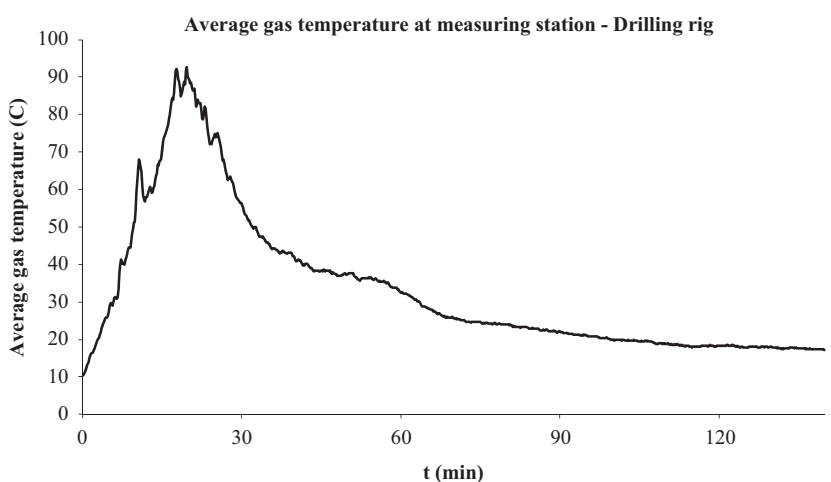

Fig. 20. The average gas temperature at the measuring station in the case of the drilling rig fire at measuring station $+47 \mathrm{~m}$.

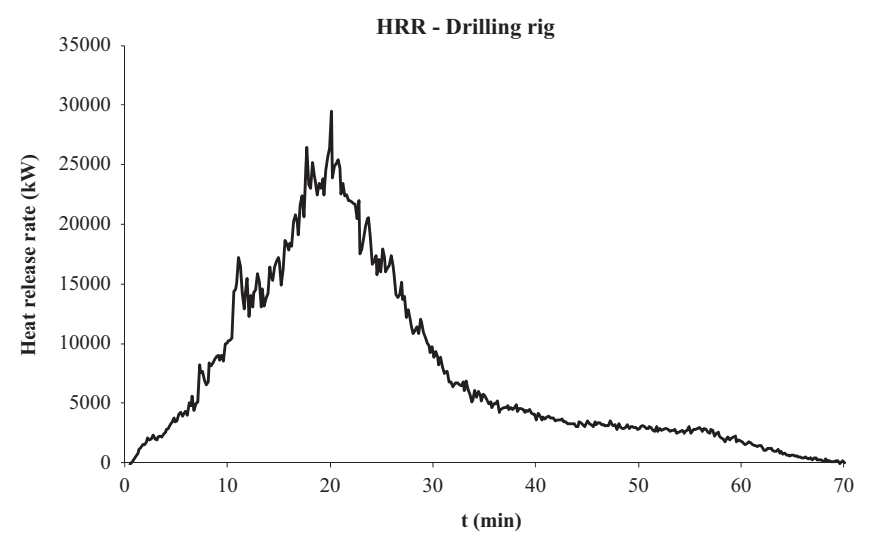

Fig. 21. The calculated heat release rate of the drilling rig.

The maximum heat release rate from the experiment was 29.4 MW. The maximum heat release rate was attained after $21 \mathrm{~min}$.

When examining the remains after the drilling rig experiment it was found that a portion of the hydraulic oil did not participate in the fire as apparently a hydraulic hose had busted and hydraulic oil being released. The hydraulic hoses approximately $2 \mathrm{~m}$ in front of the cab and forward, some amount of hydraulic oil as mentioned above, the water hose and the low voltage cable on the cable reel had not participated in the fire.

Using the measured heat release rate curve the energy content of the combustible materials consumed in the fire was calculated at $30.9 \mathrm{GJ}$. It was estimated that $600 \mathrm{~m}$ of hydraulic hoses, $70 \%$ of the hydraulic oil, the tyres, $600 \mathrm{~m}$ of electrical cables (thus excluding the $100 \mathrm{~m}$ found on the cable reel and assuming that the remaining cables would be fully consumed as practically no cables are found on the boom), the cab and $60 \mathrm{l}$ of diesel had participated in the fire. When summing up the energy contents of the materials participating in the fire and found in Table 5, the summation results in an energy content of $32.5 \mathrm{GJ}$. The difference between the estimated energy content using an inventory and the calculated energy content - integrating the resulting heat release rate curve was about $5 \%$. This is a slight difference and is most likely due to the same uncertainties as in the case of the wheel loader, i.e. when primarily estimating the amount of combustibles available and to some extent the amount of combustibles consumed in the fire.

\subsection{Uncertainty analysis of the heat release rate measurements}

An uncertainty analysis was performed for the HRR measurements of the two experiments. The results show that the combined expanded relative standard uncertainty with a $95 \%$ confidence interval was $17.6 \%$. The volume flow measurements had the largest impact on the results ( $8.2 \%)$, followed by the E-factor (2.5\%) (i.e. the factor $13,100 \mathrm{~kJ} / \mathrm{kg}$ ) and the oxygen measurements (2.2\%). When comparing with the corresponding uncertainty analysis performed for the full-scale fire experiments at Runehamar [4] it was found that the combined expanded relative standard uncertainty was at $14.9 \%$ and that the contribution of the volume flow measurements was $6.7 \%$. Thus the uncertainty of the full-scale fire experiments performed in the mine drift in Sala was higher than for the corresponding tests performed at Runehamar and the contribution of the volume flow measurements had the largest impact on this result. When studying the volume flow measurements it was found that the cross sectional area of the mine drift had the largest impact on the outcome, which was due to the very rough and uneven surface of the mine drift. In laboratory experiments - i.e. room corner experiments - the uncertainty varied between $7.1 \%$ and $13.5 \%$ [17].

Regarding the issue of having only one measuring point with respect to the $\mathrm{O}_{2}$-measurements; it was found during the analysis that the $\mathrm{O}_{2}$-measurements correlated well with the temperature measurements in the corresponding segments for both experiments. Also, earlier experiments where the same method has been applied have shown that the output results matched the actual results well [4].

\section{Discussion}

In the following a discussion on the fire development for each of the tests is presented. This detailed discussion is based on observations and analysis of the measurements obtained in the tests. Based on these discussions some final conclusions on the fire development for these two types of vehicles will be presented.

\subsection{Test 1 with wheel loader}

After about 2 min after ignition the right, rear tyre was ignited, and after approximately 8 min after ignition the left, rear tyre was ignited. Approximately $10 \mathrm{~min}$ after ignition the backlayering became too large and the mobile fan had to be moved further back, closer to the entrance to the mine (see Fig. 3 for the location). Eighteen minutes after ignition there was a sudden increase in the intensity, possibly a hydraulic hose bursting. Thirty-five minutes after ignition the right, rear tyre burst. Thirty-seven minutes after ignition rocks started to fall from the ceiling. Four hours and 20 min after ignition the mobile fan was shifted into a lower gear, a few minutes later it was shifted back again. The measurements were stopped $5 \mathrm{~h}$ and $23 \mathrm{~min}$ after ignition and the extinguishment of the remaining fire took place. The fire turned out to be very difficult to entirely extinguish due to the glowing fires in the remaining parts of the tyres. Glowing fires producing a lot of smoke and occasionally flaming fires actually occurred a week after the fire experiment. The glowing fires were difficult to extinguish as the entire vehicle was pressing down and resting on the glowing remains of the tyres. In a real fire situation the problem would have been easy to solve as towing the vehicle a short distance would have uncovered the glowing fire and made extinguishment easy. But due to a pressed timetable - as the drilling rig would be positioned right behind the wheel loader and measuring devices set up with only a couple of days to spare - it was decided that towing would not take place but instead the glowing fires were held down with occasional doses of dry powder.

After approximately $80 \mathrm{~min}$ from ignition the thermocouple at the right, forward tyre (see Fig. 6 and Table 5 for position of the thermocouple $\mathrm{Tc} 12$ ) registered temperatures about $630^{\circ} \mathrm{C}$, but 
ignition did not occur. Unfortunately the plate thermometer at the tyre stopped functioning after approximately $40 \mathrm{~min}$ from ignition and thus the incident heat flux at the tyre could not be determined, but during the first $40 \mathrm{~min}$ the incident heat flux at the right, forward tyre never exceeded $13.7 \mathrm{~kW} / \mathrm{m}^{2}$ and would thus explain why ignition of the tyre in question did not occur during this time interval if assuming a critical heat flux of $17.1 \mathrm{~kW} / \mathrm{m}^{2}$ [18] for natural rubber. See Figs. 22 and 23 for the measurements at the thermocouple at the right, forward tyre and the four plate thermometers.

The sudden increase from ambient temperature up towards $630^{\circ} \mathrm{C}$ after about $80 \mathrm{~min}$ and as the right, rear tyre was fully engulfed in flames much earlier than this point of time, the increase in temperature must be contributed to the fire in hydraulic hoses and electrical cables close to the thermocouple above the right, forward tyre. This conclusion is further enforced by the fact that the thermocouple was shielded from the flames of the rear tyre by the construction of the vehicle and the sudden decrease in temperature after a fairly short time interval due to the fact that the fire in the hydraulic hoses and electrical cables did not spread beyond the waist of the vehicle.

Unfortunately the thermocouple (Tc24) above the wheel loader (see Fig. 5) stopped working after approximately $37 \mathrm{~min}$. When comparing the temperature curve found in Fig. 22 with the heat release rate curve found in Fig. 15 for the first 20 min it can be seen that the appearance of the two curves matches well with each other. The maximum value occurred in both cases after approximately $12 \mathrm{~min}$. This observation further strengthens the validity in the heat release rates measured.

The other thermocouple above the wheel loader (Tc23) stopped functioning after less than 20 min from ignition.

When studying the temperature at the left, rear tyre (Tc13) it can be seen that the temperature increased rapidly after approximately

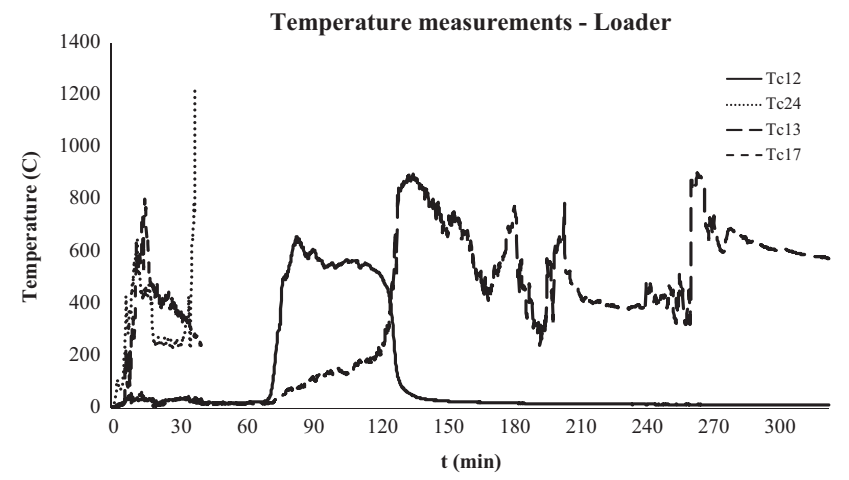

Fig. 22. The temperature at the right, forward tyre (Tc12), above the loader (Tc24), left rear tyre (Tc13) and the interior of the cab (ceiling) (Tc17).

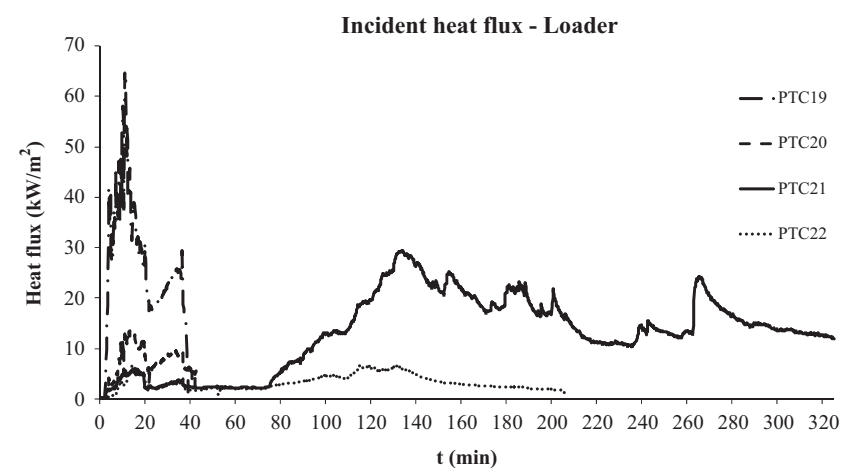

Fig. 23. The incident heat flux at the four plate thermometers.
$130 \mathrm{~min}$, most likely this was due to that the left, rear tyre was initially and at an early stage ignited at the inner surface facing the pool fire, the flames then slowly spread across the tyre and finally reaching the opposite side facing the thermocouple.

The temperature in the cab (Tc17) rapidly reached temperatures around $800{ }^{\circ} \mathrm{C}$ after approximately $15 \mathrm{~min}$ after ignition and was by then engulfed in flames, the temperature then gradually decreased and reached $300{ }^{\circ} \mathrm{C}$ after approximately $40 \mathrm{~min}$. The interior of the cab was thus rapidly consumed in the fire.

The initial rapid increase in the incident heat flux at the right rear tyre (PTC19) was contributed to the incident heat flux from the pool fire and then gradually the flames reaching the outer surface facing the plate thermometer directly. As can be seen the incident heat flux at the left forward tyre (PTC22) never exceeded $10 \mathrm{~kW} / \mathrm{m}^{2}$ and thus explaining that ignition of this tyre did not take place. The incident heat flux at the left rear tyre (PTC21) was initially at lower values but started to increase after about $80 \mathrm{~min}$ and reaching a maximum after about $140 \mathrm{~min}$, this is due to that the tyre was initially ignited at the inner surface facing the pool fire and then slowly and eventually the flames reached the surface facing the plate thermometer.

The resulting heat release rate curve of the wheel loader displayed a fire that was dominated by initially the sudden increase of the pool fire and when the first tyre was engulfed by flames and then by the slowly declining heat release rates of the large tyres of the vehicle. Still, the stop of fire spread from the waist and forward clearly shortened the duration of the fire considerably.

The initial sharp rise and high heat release rate for the first 20 min of the fire can be explained mainly due to the pool fire and the fire in the rear, right tyre. The sharp drop after about 20 min was due to the pool fire burning off. The burn off time of the diesel pool fire at the wheel loader fire experiment was calculated to about $43 \mathrm{~min}$ (assuming a regression rate of $0.066 \mathrm{~kg} / \mathrm{s} \mathrm{m}^{2}$ (deep pool)). Assuming a maximum heat release rate per unit area of $1.33 \mathrm{MW} / \mathrm{m}^{2}$ [19] for thick fuel bed, the maximum heat release rate of the diesel pool fire was calculated to be $1.26 \mathrm{MW}$. When studying the heat release rate curve in Fig. 15, the decrease in heat release rate was about $8 \mathrm{MW}$ which was much larger than the calculated $1.26 \mathrm{MW}$ of the pool fire. The difference can be explained by the fact that the diesel tank of the wheel loader was not equipped with a magnetic valve - as in the case of the drilling rig - which suggest that the fuel hoses in the proximity of the fuel tank could have been burned off during the early stages, draining the tank and thereby increasing the size of the pool fire and consequently the heat release rate of the diesel pool fire. Also the pool fire was underneath the wheel loader and thus the reradiation back to the pool surface would be much larger than for a free standing pool fire and thus the heat release rate would be larger. This observation is further enforced by the fact that the calculated burn off time of the diesel pool fire was more than twice as long as the observed burn off time. But the differences will have to be investigated further in order to fully explain them.

The slow increase in heat release from about $20 \mathrm{~min}$ to about 50 min was due to the slow flame spread along the surface of the rear, left tyre. The sudden - and temporary - decrease in the ventilation velocities and heat release rate approximately $10 \mathrm{~min}$ after ignition can be related to the change of position of the mobile fan, where the fan was geared down temporarily during the transport. A maximum backlayering of approximately $50 \mathrm{~m}$ was visually observed during the experiment. The corresponding average longitudinal ventilation rate was $1.6 \mathrm{~m} / \mathrm{s}$.

\subsection{Test 2 with drilling rig}

Approximately 2 min after ignition both rear tyres were ignited and the fire spread further to hydraulic hoses in the rear, upper 
part. After about 12 min after ignition the right, forward tyre was ignited. At about the same time a sudden increase in intensity occurred, most likely due to that the right, rear tyre burst. After 26 min there was a second sudden increase in intensity, due to that the right front tyre burst. Two hours and 25 min after ignition the measurements were stopped and the remaining fire was extinguished.

The temperature at the forward part of the boom - where the hydraulic hose did not ignite and burn - exceeded $930{ }^{\circ} \mathrm{C}$ after approximately $25 \mathrm{~min}$ from ignition (see Fig. 7 and Table 6 for the position of thermocouple Tc34). It is unclear why the hydraulic hoses did not ignite and burn. It could possibly and partially be explained by the hydraulic hoses already being drained of all hydraulic oil and thus decreasing the heat release rate and the fire spread when initially ignited. The incident radiation level was simply too low to propagate the fire in the direction of the ventilation flow. The temperature measurements at the forward part of the boom can be seen in Fig. 24. As can be seen the temperature in the forward part of the boom reached temperatures above $730{ }^{\circ} \mathrm{C}$ at an early stage of the fire, which could be contributed to the strong longitudinal ventilation flow of the mobile fan as the thermocouple was positioned at a low position, i.e. on the loosely hung bundle of hydraulic hoses on the boom. The sudden increase in temperature could be explained by that the longitudinal ventilation velocity at that stage reached a velocity that bend the plume sufficiently to be able to reach the thermocouple.

The maximum temperature above the drilling rig (Tc35) at $459{ }^{\circ} \mathrm{C}$ occurred after approximately $21 \mathrm{~min}$ (the same time as the maximum heat release rate). Furthermore, the appearance of the curve in Fig. 21 and the temperature above the drilling rig in Fig. 24 were similar and thus all these observations strengthened the reliability of the heat release rate in Fig. 21.

Thermocouple Tc36 showed identical results with Tc35.

The temperature in the cab (Tc17) increased to about $800{ }^{\circ} \mathrm{C}$ in less than $10 \mathrm{~min}$ from ignition; the cab was thus ignited at an early stage of the fire. The temperature started to decrease from the higher temperatures of $800-1000{ }^{\circ} \mathrm{C}$ after $25 \mathrm{~min}$ from ignition. Same as for the case of the wheel loader, the fire in the cab was rapid in fire growth and the interior was quickly consumed in the fire.

At the waist of the drilling rig the temperature (Tc23) reached temperatures around $800{ }^{\circ} \mathrm{C}$ after $6 \mathrm{~min}$. The hydraulic hoses in the waist were most likely in flames at this time.

Fig. 25 shows the incident heat flux at the plate thermometers and as can be seen the plate thermometer at the left, forward tyre (PTC22) stopped functioning after approximately 9 min. The plate thermometer at the right rear tyre (PTC19) initially showed the highest values as this plate thermometer was placed closest to the

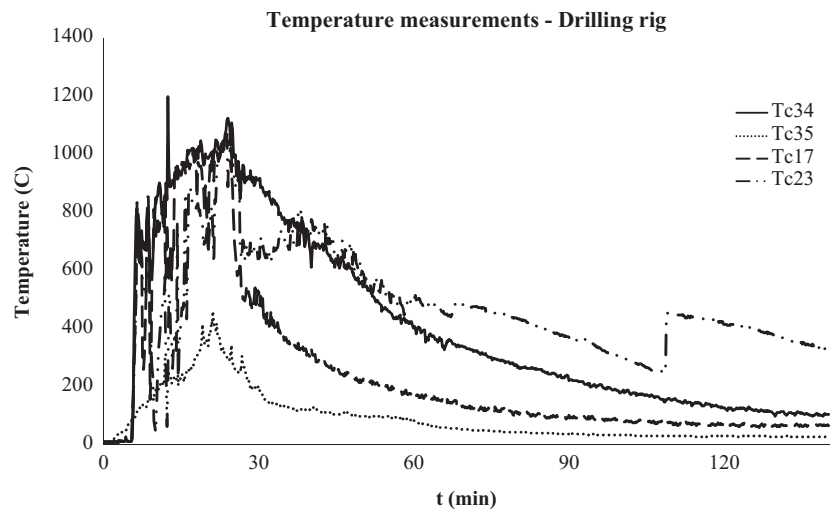

Fig. 24. The temperature at the forward part of the boom (Tc34), above the drilling rig (Tc35), interior of the cab (ceiling) (Tc17) and the lower part of the waist (Tc23).

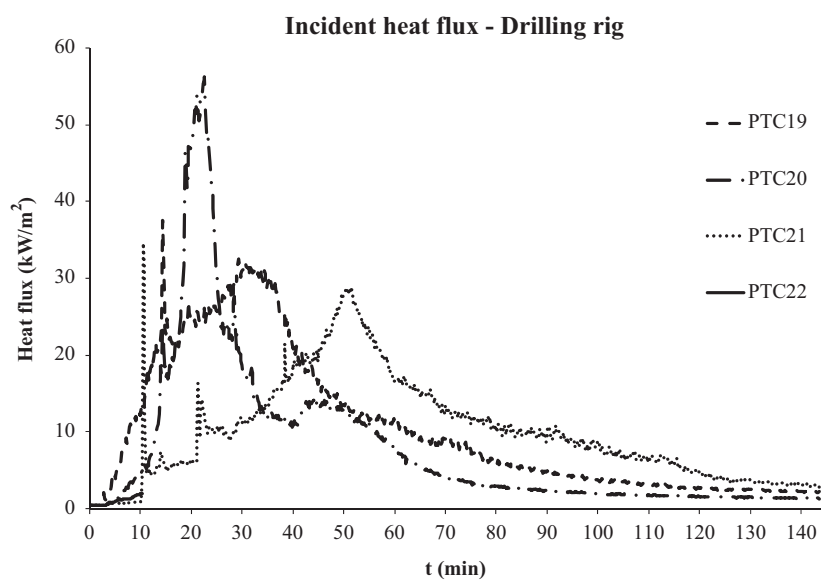

Fig. 25. The incident heat flux at the four plate thermometers.

pool fire. The plate thermometer at the right forward tyre (PTC20) showed a sudden increase after approximately 12 min which coincided with the ignition of the tyre. The plate thermometer at the left rear tyre (PTC21) showed a sudden peak after approximately 12 min which was due to the sudden increase in intensity due to the rupture of the opposite tyre. After that the incident heat flux slowly increased as the flames eventually reached the side facing the plate thermometer.

The resulting heat release rate curve of the drilling rig displayed a fire with high heat release rates and relatively short lived - compared with the fire in the wheel loader. Practically all the combustible items were ignited in the early phases of the fire.

A sudden increase in fire growth can be seen in Fig. 21 after approximately $13 \mathrm{~min}$, this was due to the ignition of the right, forward tyre.

A maximum backlayering of approximately $70 \mathrm{~m}$ was visually observed during the experiment. The corresponding average longitudinal ventilation rate was $2.6 \mathrm{~m} / \mathrm{s}$.

With respect to the longitudinal ventilation and backlayering, the differences in the two experiments demonstrated the importance of establishing a distinct pressure in the mine drift which will take time due to the extensive and complex geometry. This stresses the importance of not changing the ventilation too fast but awaiting change before alternating the ventilation.

The longitudinal ventilation will also affect the heat release rate of the tyres due to the threads of the tyre, containing voids with separate and protected atmospheres. An increasing longitudinal ventilation velocity will increase the air supply into the voids and thus increase the heat release rate.

\section{Conclusions}

Two full scale fire experiments were carried out in an operative underground mine in Sweden. The fire experiments were carried out using a wheel loader and a drilling rig. The measured parameters during the full scale fire experiments were: the heat release rate, the temperatures and the incident radiation heat fluxes at certain points, the ventilation velocities in the mine drift; and the oxygen, carbon monoxide and carbon dioxide levels.

The results of the full-scale fire experiments show that in the experiment involving the wheel loader that the front part of the vehicle with front tyres etc. never ignited. The maximum heat release rate from the experiment was $15.9 \mathrm{MW}$ and it was attained approximately $11 \mathrm{~min}$ after ignition. A portion of the heat release rate could possibly be attributed to a higher heat release rate due to a higher evaporation of the pool fire due to a higher degree of 
re-radiation and a possible leakage of the diesel tank, but the issue will have to be investigated further.

The maximum backlayering distance of the wheel loader fire was approximately $50 \mathrm{~m}$. The resulting heat release rate curve of the wheel loader fire displays a fire that is dominated by initially the sudden increase of the pool fire and when the first tyre is engulfed by flames and then by the slowly declining heat release rates of the large tyres of the vehicle. Still, the stop of fire spread from the waist and forward clearly shortened the duration of the fire considerably.

It was found in the experiment with the drilling rig that except for the hydraulic hoses approximately $2 \mathrm{~m}$ in front of the cab and forward, some amount of hydraulic oil as mentioned above and a major part of the low voltage cable on the cable reel, the entire vehicle had participated in the fire and the combustible material had been consumed. The maximum heat release rate from the experiment was $29.4 \mathrm{MW}$ and it was attained after $21 \mathrm{~min}$. The maximum backlayering distance of the drilling rig fire was about $70 \mathrm{~m}$. The resulting heat release rate curve of the drilling rig displays a fire with high heat release rates and relatively short lived-compared with the fire in the wheel loader. Practically all the combustible items were ignited in the early phases of the fire.

The differences between the estimated energy content using inventories and the calculated energy contents - integrating the resulting heat release rate curves - were relatively small or very slight. The difference is most likely due to the uncertainties when estimating the amount of combustibles available and to some extent the amount of combustibles consumed in the fire.

When calculating the heat release rate in the two cases, the applied method included some uncertainties. An uncertainty analysis showed that the combined expanded relative standard uncertainty with a $95 \%$ confidence interval was $17.6 \%$. It turned out that the volume flow measurements had the largest impact on the results $(8.2 \%)$, followed by the $\mathrm{E}$-factor $(2.5 \%)$ and the oxygen measurements (2.2\%).

The fires in both cases were fuel controlled throughout the entire sequence, due to the high minimum oxygen level and low maximum level of the carbon monoxide.

The differences in the two experiments - with respect to longitudinal ventilation and backlayering - demonstrated the importance of establishing a distinct pressure in the mine drift which will take time due to the extensive and complex geometry. This stresses the importance of not changing the ventilation too fast in an underground mine but awaiting change before alternating the ventilation.

Further validation work should take place with respect to validating the experimental data with output data from theoretical models and the output data from the cone calorimeter experiments and the TPS experiments.

\section{Acknowledgement}

The project was sponsored by the Swedish Knowledge Foundation (KK-stiftelsen), LKAB Mining Corporation, Atlas Copco Rock Drills $A B$ and Björka Mineral AB.

\section{References}

[1] R. Hansen, Literature Survey-Fire and Smoke Spread in Underground Mines, Mälardalens Högskola, MdH SiST 2009:2, Västerås, 2009

2] M.I. De Rosa, Analysis of Mine Fires for all US Metal/Non-metal Mining Categories, 1990-2001, National Institute for Occupational Safety and Health -NIOSH, 2004.

[3] Alternativ till utrymningsväg från gruva och annan underjordsanläggning, Svenska Gruvföreningen, 1985 (in Swedish).

[4] H. Ingason, A. Lönnermark, Heat release rates from heavy goods vehicle trailers in tunnels, Fire Safety Journal 40 (2005) 646-668.

[5] C. Huggett, Estimation of rate of heat release by means of oxygen consumption measurements, Fire and Materials 4 (1980) 61-65.

[6] H. Ingason, Fire Test with a Front Wheel Loader, SP Swedish National Testing and Research Institute, Borås, Sweden, 2008. (SP report P801596).

[7] M. Simonson, M. Milovancevic, H. Persson, Hydraulic Fluids in Hot Industry: Fire Characteristics and Fluid Choice, SP Report 1998:37, Borås, 1998.

[8] G.E. Totten, S.R. Westbrook, R.J. Shah, Fuels and Lubricants Handbook: Technology, Properties, Performance, and Testing, vol. 1, ASTM International, 2003.

[9] A. Tewarson, Generation of heat and chemical compounds in fires, in: P.J. DiNenno, D. Drysdale, C.L. Beyler, W.D. Walton, R.L.P. Custer, J.R. Hall, J. M. Watts (Eds.), The SFPE Handbook of Fire Protection Engineering, NFPA, Quincy, USA, 2002.

[10] K. McGrattan, Fire Dynamics Simulator (Version 5) User's Guide, NIST, Gaithersburg, 2009. (NIST Special Publication 1019-5).

[11] R. Hansen, Investigation on Fire Causes and Fire Behaviour-Vehicle Fires in Underground Mines in Sweden, To be published, Mälardalens Högskola, Västerås, Sweden.

[12] H. Ingason, Correlation between temperatures and oxygen measurements in a tunnel flow, Fire Safety Journal 42 (2006) 75-80.

[13] J.S. Newman, Experimental evaluation of fire-induced stratification, Combustion and Flame 57 (1984) 33-39.

[14] B.J. McCaffrey, G. Heskestad, Brief communications: a robust bidirectional lowvelocity probe for flame and fire application, Combustion and Flame (1976) $125-127$.

[15] H. Ingason, U. Wickström, Measuring incident radiant heat flux using the plate thermometer, Fire Safety Journal 42 (2007) 161-166.

[16] M. Arvidson M., H. Ingason, Measurement of the Efficiency of a Water Spray System Against Diesel Oil Pool and Spray Fires, SP Report 2005:33, Borås, Sweden, 2005.

[17] J. Axelsson, P. Andersson, A. Lönnermark, P. Van Hees, I. Wetterlund, Uncertainties in Measuring Heat and Smoke Release Rates in the Rom/Corner Test and the SBI, SP Swedish National Testing and Research Institute, Borås, Sweden, 2001. (SP Report 2001:04).

[18] V. Babrauskas, Ignition Handbook, Fire Science Publishers, Issaquah, 2003.

[19] A. Lönnermark, P. Kristensen, M. Helltegen, M. Bobert, Fire Suppression and Structure Protection for Cargo Train Tunnels: Macadam and Hotfoam, International Society for Traumatic Stress Studies-ISTSS, 2008. 